\title{
The Forgotten Half of Food System Reform: Using Food and Agricultural Law to Foster Healthy Food Production
}

\section{Citation}

Broad Leib, Emily M. "The Forgotten Half of Food System Reform: Using Food and Agricultural Law to Foster Healthy Food Production," 9 J. Food L. \& Pol'y 17 (2013).

\section{Permanent link}

http://nrs.harvard.edu/urn-3:HUL.InstRepos:11189866

\section{Terms of Use}

This article was downloaded from Harvard University's DASH repository, and is made available under the terms and conditions applicable to Open Access Policy Articles, as set forth at http:// nrs.harvard.edu/urn-3:HUL.InstRepos:dash.current.terms-of-use\#OAP

\section{Share Your Story}

The Harvard community has made this article openly available.

Please share how this access benefits you. Submit a story.

\section{Accessibility}




\title{
THE FORGOTTEN HALF OF FOOD SYSTEM REFORM: USING FOOD AND AGRICULTURAL LAW TO FOSTER HEALTHY FOOD PRODUCTION
}

\author{
Emily Broad Leib*
}

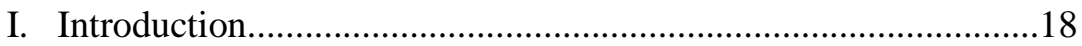

II. Background: The Food System and the Obesity Crisis................20

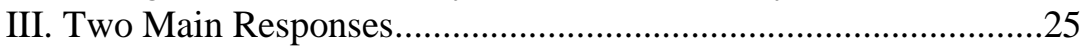

A. Option 1: Reforming the Industrial System...........................26

B. Option 2: Improving Viability of the Alternative

Food System........................................................................ 31

1. Demand for Healthy Food is Increasing, yet too little of Our current production focuses on specialty crops............34

2. Reforming the Industrial Food System Alone will not Ensure Increased Production of Healthy Foods on the timetable needed.

3. Supporting the Alternative Food System is Necessary to the goal of Making Healthy Foods More Available and Affordable. 38

IV. Barriers to the Alternative Food System

A. Programmatice and Policy Barriers to Small Food Producers...

B. Legal and Regulatory Hurdles.

C. Barriers to Mid-Size Producers and the Agriculture Of the Middle.

V. The Role for Lawyers in Supporting the Alternative Food System.....

A. Provide Legal Assistance to Alternative Food System Producers.

B. Advocate for Policy Change to Reduce Barriers

to Small Food Producers.

VI. Conclusion.

* Emily Broad Leib is Director of the Harvard Law School Food Law and Policy Clinic. The author would like to thank the AALS Agricultural and Food Law Section for the invitation to present on this topic; Margaret Sova McCabe, Susan Schneider, Baylen Linnekin, Nathan Rosenberg, Steven Herman, and Sarah Downer for their helpful feedback; and Ona Balkus for diligent and insightful research assistance. 


\section{Introduction}

America is facing widespread problems with its food system, including environmental harms due to externalities from industrial farms; ${ }^{1}$ the increasing amount of "food miles" traveled by the products that make up our daily meals; $;^{2}$ and the growing size and complexity of recent outbreaks of foodborne illnesses. ${ }^{3}$ Indeed, the entire system that covers the life cycle of food, through production, processing, distribution, consumption, and food waste management, is in crisis. One of the most disturbing of these well-documented problems with the industrial food system is the increase in rates of obesity and diet-related illnesses. Obesity rates in the U.S. have more than doubled since $1980 .^{4}$ Rising rates of obesity stem from what has been called a "toxic" food culture, in which unhealthy food products are cheap and readily available, ${ }^{5}$ while healthy foods are unavailable in many urban and rural food deserts ${ }^{6}$ or out of reach for those with limited economic means. ${ }^{7}$

1. See, e.g., William S. Eubanks II, A Rotten System: Subsidizing Environmental Degradation and Poor Public Health with Our Nation's Tax Dollars, 28 STAN. ENVTL. L.J. 213, 251-72 (2009); J.B. Ruhl, Farms, Their Environmental Harms, and Environmental Law, 27 ECOLOGY L.Q. 263, $274-93$ (2000); Susan A. Schneider, Reconsidering the Industrialization of Agriculture, 26 J. ENVTL. L. \& LITIG. 19, 21-25 (2011).

2. See, e.g., Rich Pirog \& Andrew Benjamin, Checking the Food Odometer: Comparing Food Miles for Local Versus Conventional Produce Sales to Iowa Institutions, LEOPOLD CENTER FOR SUSTAINABLE AGRIC., 1 (2003), available at http://www.leopold.iastate.edu/sites/default/files/pubs-and-papers/2003-07-checkingfood-odometer-comparing-food-miles-local-versus-conventional-produce-sales-iowainstitution.pdf; Marne Coit, Jumping on the Next Bandwagon: An Overview of the Policy and Legal Aspects of the Local Food Movement, 4 J. FoOD L. \& PoL'Y 45, 50 (2008); Lauren Kaplin, Energy (In)efficiency of the Local Food Movement: Food for Thought, 23 FORDHAM ENVTL. L. REV. 139 (2012).

3. See, e.g., Michael T. Roberts, Mandatory Recall Authority: A Sensible and Minimalist Approach to Improving Food Safety, 59 FoOD \& DRUG L.J. 563, 565 (2004); Nathan M. Trexler, "Market” Regulation: Confronting Industrial Agriculture's Food Safety Failures, 17 WIDENER L. REV. 311, 330 (2011).

4. See Cynthia L. Ogden et al., Prevalence of Overweight and Obesity in the United States, 1999-2004, 295(13) J. AM. MED. Ass'N 1549 (Apr. 2006).

5. See, e.g., E. Katherine Battle \& Kelly D. Brownell, Confronting a Rising Tide of Eating Disorders and Obesity: Treatment vs. Prevention and Policy, 21 ADDICTIVE BEHAV. 755, 761-62 (1996); Katherine Pratt, A Constructive Critique of Public Health Arguments for Anti-obesity Soda Taxes and Food Taxes, 87 TUL. L. REV. 73, 115-16 (2012).

6. Nareissa Smith, Eatin' Good? Not in This Neighborhood: A Legal Analysis of Disparities in Food Availability and Quality at Chain Supermarkets in PovertyStricken Areas, 14 MicH. J. RACE \& L. 197, 216 (2009) (discussing the lack of food access in low-income, generally minority communities but not using the term "food 
To improve public health outcomes, and mitigate the impact of obesity and related illnesses, our food and agricultural system requires a transformation. Most discussions about how to overhaul our food and agriculture system focus on reforming or dismantling the industrial, commodity-based food system by erecting barriers to the production and sale of unhealthy, overly-processed foods. This could entail reducing or eliminating agricultural subsidies, utilizing taxes or regulations to force industrial food producers to internalize the costs of their negative impacts on health and the environment, or decreasing consumer access to or demand for these products by implementing marketing restrictions, labeling requirements, or bans on certain foods or ingredients.

While we will surely need to reform and reign in the industrial food system, this article contends that those reforms are only part of the battle, and will not necessarily make healthier foods more readily available in the immediate future. We also need to think about the other half of the picture-increasing the production and availability of healthier foodswhich will require improving the climate for the production of healthy "specialty crops" (defined as "fruits, vegetables, tree nuts, dried fruits, horticulture, and nursery crops"). ${ }^{8}$ This avenue would lead to a focus on supporting alternative, small and mid-size food producers, who are and will likely remain the primary producers of specialty crops, and would require investments of time, energy, and resources into alternative food production. To encourage sufficient production of specialty crops, we must also reduce the programmatic, policy, and legal barriers that stand in the way of these producers.

This article first describes the obesity and public health issues facing the United States and explains their links to the food and agricultural

desert”); Susan A. Schneider, A Reconsideration of Agricultural Law: A Call for the Law of Food, Farming, and Sustainability, 34 WM. \& MARY ENVTL. L. \& POL'Y REV. 935, 955 (2010); Good Food: Examining the Impact of Food Deserts on Public Health in Chicago, MARI GALlaGHER RESEARCH AND CONSUlting GRP., 5 (2006), available at http:// www.marigallagher.com/site_media/ dynamic/project_files/Chicago_Food _Desert_Report.pdf; Tess Feldman, Re-Stocking the Shelves: Policies and Programs Growing in Food Deserts, 16 PUB. INT. L. REP. 38, 39 (2010).

7. Food Security in the U.S.: Key Statistics and Graphics, U.S. DEP'T OF AGRIC., ECON. RESEARCH SERV., http://www.ers.usda.gov/topics/food-nutritionassistance/food-security-in-the-us/key-statistics-graphics.aspx\#foodsecure (last updated Sept. 4, 2012) (noting that 14.9 percent of U.S. households, or 17.9 million people, were food insecure at some time during 2011).

8. Specialty Crop Block Grant Program-Farm Bill, U.S. DEP'T OF AGRIC., AGRIC. MKTG. SERV., http://www.ams.usda.gov/AMSv1.0/ams.fetch Template Data.do? template $=$ TemplateN\&navID $=$ SpecialtyCropBlockGrant $\% 20$ Program\&rightNav $1=$ Spe cialtyCropBlockGrant $\% 20$ Program $\&$ topNav $=\&$ leftNav $=\&$ page $=S C B G P \&$ resultType $=$ \&acct=fvgrntprg (last visited Feb. 20, 2013). 
system. Part III then discusses the two primary avenues for food system reform and illustrates the reasons we should focus more energy and resources than we currently do on supporting alternative food producers. Part IV. lays out some key barriers to alternative food producersincluding programmatic and policy barriers, legal and regulatory hurdles, and obstacles that particularly impact mid-scale food producers, even though these mid-scale producers offer the most potential to increase healthy food access on the scale needed. Finally, Part V discusses the reasons for which the legal profession should use its unique skills to support alternative food producers and presents several important ways in which attorneys can play a key role in improving the viability of the alternative food system, thus promoting better public health outcomes by ensuring that fruits, vegetables, and other healthy foods will become more readily available.

\section{Background: The Food System and the Obesity Crisis}

The United States, along with the rest of the globe, is in the midst of an obesity epidemic. ${ }^{9}$ In 2010, the majority of Americans weighed more than medically recommended, with approximately 36 percent considered to be obese and an additional 33 percent overweight. ${ }^{10}$ With some recent exceptions in specific populations, ${ }^{11}$ rates of obesity among children have been steadily climbing as well, with data showing a nearly 17 percent obesity rate among children and teens. ${ }^{12}$ In addition to the high obesity rates, just over 8 percent of Americans suffer from diabetes and approximately 35 percent are pre-diabetic. ${ }^{13}$ Indeed, three of the top causes

9. See High Level Meeting on Non-communicable Diseases, GEN. AsSEMBLY of THE UNITED NATIONS, http://www.un.org/en/ga/president/65/issues/ncdiseases.shtml (last visited Feb. 25, 2013); The Maladies of Affluence, THE ECONOMIST (Aug. 9, 2007), http://www.economist.com/node/9616897.

10. Katherine M. Flegal, et al., Prevalence of Obesity and Trends in the Distribution of Body Mass Index Among US Adults, 1999-2010, 307(5) J. AM. MED. Ass'N 491, 493 (2012).

11. Liping Pan et al., Trends in the Prevalence of Extreme Obesity Among US Preschool-Aged Children Living in Low-Income Families, 1998-2010, 308(24) J. OF THE AM. MED. ASS'N 2563, 2564 (2012) (finding a small but significant decline in obesity and extreme obesity rates from 2003 to 2010 in low-income children ages 2-4 in certain populations).

12. Cheryl D. Fryar, et al., Prevalence of Obesity Among Children and Adolescents: United States, Trends 1963-1965 Through 2009-2010, Centers for Disease Control and Prevention, Nat'l Center for Health Statistics, 5 (2012), available at http://www.cdc.gov/nchs/data/hestat/obesity_child_09_10/obesity_child_09_10.pdf.

13. National diabetes fact sheet: national estimates and general information on diabetes and prediabetes in the United States, U.S. Dep't of Health and Human Serv., 
of death in the United States (heart disease, cancer, and stroke) have been linked consistently with poor diet. ${ }^{14}$

U.S. healthcare spending reflects these high rates of obesity and dietrelated disease. ${ }^{15}$ For example, 27 percent of the increase in healthcare expenditures from 1987-2001 was blamed on obesity, ${ }^{16}$ and in 2006, per capita healthcare expenses were 42 percent higher for obese individuals than for those with normal weight. ${ }^{17}$ The estimated medical care cost of obesity in the United States in 2008 was $\$ 147$ billion. ${ }^{18}$ In reality, the total cost is much higher, as overweight and obesity have been linked to numerous diseases - including heart disease, type 2 diabetes, certain cancers, and Alzheimer's Disease - which have their own associated costs. ${ }^{19}$ Further, all of these health problems lead to lost productivity and lost work days, posing additional costs beyond just dollars spent on medical care. ${ }^{20}$

The high incidence of overweight and obesity should come as no surprise, given the food that is readily available and affordable for most Americans and is the center of the American diet. According to data from the U.S. Department of Agriculture (USDA), Americans consumed a daily average of roughly 450 more calories in 2010 than in $1970 .{ }^{21}$ Consumption

Centers for Disease Control and Prevention, 1 (2011), available at http://www.cdc.gov/diabetes/pubs/pdf/ndfs_2011.pdf.

14. See, e.g., Richard J. Jackson et al., Agriculture Policy Is Health Policy, 4 J. HUNGER ENVTL. NUTRITION 393, 394 (2009).

15. In 2011, the U.S. spent $\$ 2.7$ trillion, or 17.9 percent of its GDP, on healthcare. Micah Hartman et al., National Health Spending In 2011: Overall Growth Remains Low, But Some Payers And Services Show Signs Of Acceleration, 32(1) HeALth AFFAIRS 87, 88 (2013). Seventy-five percent of our annual spending is attributable to chronic disease, much of which is linked with poor diet. The Power to Prevent, The Call to Control: At A Glance 2009, CENTERS FOR DiSEASE CONTROL AND PREVENTION, CHRONIC DISEASES (2009), http://www.cdc.gov/chronicdisease/resources /publications/aag/chronic.htm (last visited Feb. 20, 2013).

16. Kenneth E. Thorpe, et al., The Impact of Obesity On Rising Medical Spending, HEALTH AFF. Web Exclusives: W4-480, W4-485 (2004), http://content. healthaffairs.org/content/early/2004/10/20/hlthaff.w4.480.full.pdf.

17. Eric A. Finkelstein, et al., Annual Medical Spending Attributable To Obesity: Payer-And Service-Specific Estimates, 28(5) HEALTH AFF. w822, w826 (2009), available at http://content.healthaffairs.org/content/28/5/w822.full.pdf.

18. Id. at w828.

19. Overweight and Obesity: Causes and Consequences, CENTERS FOR DISEASE CONTROL AND PREVENTION, http://www.cdc.gov/obesity/adult/causes/index.html (last updated April 27, 2012).

20. See Barry M. Popkin et al., Measuring the full economic costs of diet, physical activity and obesity-related chronic diseases, 7(3) OBESITY REV. 271, 272 (2006).

21. Between 1970 and 2010, the average daily per capita calories from U.S. food availability, adjusted for spoilage and other waste, increased from 2,076 to 2,534. Loss 
of "corn calories" (calories from corn flour, corn meal, hominy, and corn starch) has increased 198 percent since 1970, and that of corn sweetener calories rose by 305 percent. $^{22}$ At the same time, world sugar consumption has tripled over the past 50 years and, because sugar and other sweeteners are added to so many processed foods, "people are consuming an average of more than 500 calories per day from added sugar alone." ${ }^{23}$ In contrast, there has been only a 26 percent increase in the amount of calories that Americans receive from fruit each day, and a 5.5 percent reduction in calories from vegetables. ${ }^{24}$ Americans today are eating more than ever, and a greater proportion of their food intake comes from unhealthy, highlyprocessed items as opposed to healthy, fresh fruits and vegetables.

Not only are these unhealthy foods readily available and affordable, but in many parts of the country, Americans over-consume these foods because they suffer from economic and geographic barriers to accessing alternative, healthier foods. According to the USDA, nearly 15 percent of U.S. households, or 18 million people, were food insecure-meaning they did not have access "at all times to enough food for an active, healthy life" at some time during $2011 .{ }^{25}$ Similarly, a 2012 USDA report found that almost 10 percent of the U.S. population, approximately 30 million people,

adjusted food availability, Calories Table, U.S. DEP'T OF AGRIC., ECON. RESEARCH SERV. (Nov. 2012), http://www.ers.usda.gov/Data/FoodConsumption/FoodGuide Index.htm.

22. These figures were calculated by determining the percentage increase from the calories available daily in the U.S. based on exports, imports, and food losses between 1970 and 2010. For corn products, the calories available daily rose from 36.1 to 107.4 between 1970 and 2010 and for corn sweeteners the calories available daily rose from 44.2 to 178.9 between 1970 and 2010. The Economic Research Services uses food availability data as a proxy for food consumption (see Summary Findings). Loss adjusted food availability, Grains Table, Total Corn Products tab and Sugar Table, Corn Sweeteners tab, U.S. DEP'T OF AGRIC., ECON. RESEARCH SERV. (Nov. 2012), http://www.ers.usda.gov/Data/FoodConsumption/FoodGuideIndex.htm.

23. Robert H. Lustig, et al., The Toxic Truth About Sugar, 482 NATURE 27, 28 (Feb. 2012).

24. For fruit, the calories available daily rose from 64.8 to 81.8 between 1970 and 2010. For vegetables, the calories available daily declined from 132.0 to 124.8 between 1970 and 2010. Loss adjusted food availability, Fruit Table and Vegetables Table, U.S. DeP'T OF Agric., ECON. RESEARCH SERV. (Nov. 2012), http://www.ers.usda.gov/Data /Food Consumption/FoodGuideIndex.htm.

25. Food Security in the U.S., Key Statistics and Graphics, U.S. DEP'T OF AGRIC., ECON. RESEARCH SERV., http://www.ers.usda.gov/topics/food-nutrition-assistance /food-security-in-the-us/key-statistics-graphics.aspx\#foodsecure (last updated Sept. 4, 2012). The USDA defines food security as "access by all people at all times to enough food for an active, healthy life." Food Security in the U.S., Overview, U.S. DEP'T OF AGRIC., ECON. RESEARCH SERV. http://www.ers.usda.gov/topics/food-nutritionassistance/food-security-in-the-us.aspx (last updated Sept. 4, 2012). 
live in food deserts, ${ }^{26}$ areas that "lack access to affordable fruits, vegetables, whole grains, low-fat milk, and other foods that make up the full range of a healthy diet." ${ }^{27}$ Even those who have access to grocery stores and retail outlets where they can purchase fresh, healthy foods often have limited options due to the high cost of healthy food products relative to unhealthy ones. ${ }^{28}$ Between 1985 and 2000, the inflation-adjusted price of fresh fruits and vegetables rose by 39 percent, while the price of carbonated soft drinks decreased by nearly 24 percent over the same time period. ${ }^{29}$ Those in communities without access to large supermarkets or retail outlets suffer the most: according to one study, groceries in smaller

26. Michele Ver Ploeg et al., Access to Affordable and Nutritious Food: Updated Estimates of Distance to Supermarkets Using 2010 Data, U.S. DEP'T OF AGRIC., ECON. RESEARCH SERV., ERR 143, iii (Nov. 2012), http://www.ers.usda.gov/media 1956784/err143.pdf (data based on the 2010 Census, the 2006-2010 American Community Survey, and 2010 data on locations of supermarkets, supercenters, and large grocery stores). The USDA defines food deserts as low-income census tracts (poverty rate of twenty percent or higher or median family income at or below 80 percent of the area's median family income) where a substantial portion of the population has low access to supermarkets or large grocery stores (at least 500 people or at least 33 percent of the census tract's population resides more than one mile from a supermarket or large grocery store; the distance is increased to ten miles in the case of rural areas). Food Desert Locator, About the Locator, U.S. DEP'T OF AGRIC., ECON. RESEARCH SERV., http://www.ers.usda.gov/Data/FoodDesert/documentation.html (last updated Aug. 6, 2012).

27. A Look Inside Food Deserts, CENTERS FOR DISEASE CONTROL AND PREVENTION, http://www.cdc.gov/features/fooddeserts/ (last updated Sept. 24, 2012).

28. Pablo Monsivais, et al., Following Federal Guidelines to Increase Nutrient Consumption May Lead To Higher Food Costs for Consumers, 30(8) HEALTH AFF. 1 (Aug. 2011) (noting that nutrient-dense, healthy foods cost more than calorie-dense foods with minimal nutritional value). But note, a recent USDA report attested that healthy foods are not more expensive (and in some cases, may be less expensive) than unhealthy options. See Andrea Carlson \& Elizabeth Frazão, Are Healthy Foods Really More Expensive? It Depends on How You Measure the Price, U.S. DEPT OF AGRIC., ECON. RESEARCH SERV., EIB 96 (May 2012), available at http://www. ers.usda.gov/media/600474/eib96_1_.pdf. However, this report does not take into account many of the secondary costs of healthy food items (electricity and gas costs for storage and preparation; expenses for purchasing and maintaining cooking appliances; higher food waste as healthy foods are more likely to spoil; increased transportation costs as more trips are needed to maintain a supply of healthy foods; etc.). The study also does not account for the challenges faced by many citizens in accessing fresh, healthy foods in their local communities, or the fact that in many communities, residents are constrained by purchasing the foods available at small corner stores, which have limited healthy options and often charge higher prices for those food items.

29. David Wallinga, Agricultural Policy and Childhood Obesity: A Food Systems and Public Health Commentary, 29(3) HEALTH AFF. 405, 407 (2010). 
stores cost an average of 10 percent more than the same items in larger supermarkets. ${ }^{30}$

Lack of access to healthy foods, due to both economic constraints and geographic barriers, has been linked with increased rates of overweight and obesity. With regard to economic constraints, over 35 percent of individuals earning less than $\$ 15,000$ per year were obese compared to 24.5 percent of adults earning $\$ 50,000$ or more per year. ${ }^{31}$ Such figures are not surprising, as those who make more money are able to spend more on fresh, healthy foods. As evidence, households with incomes above 300 percent of the Federal Poverty Level ${ }^{32}$ spent over 50 percent per person more on fruits and vegetables than households with incomes at or below the Federal Poverty Level. ${ }^{33}$

Those who encounter geographic barriers to healthy food access also suffer disproportionately from poor health outcomes. According to a 2006 study, people living in areas without supermarkets had a 24 percent higher prevalence of obesity and 9 percent higher prevalence of overweight than those living in census tracts without supermarkets. ${ }^{34}$ Along the same lines, a 2009 study found people living in a neighborhood with a large grocery store consumed 0.69 more servings of fruits and vegetables daily than those in neighborhoods without a grocery store. ${ }^{35}$

30. Michele Ver Ploeg et al., Access to Affordable and Nutritious Food: Measuring and Understanding Food Deserts and Their Consequences, Report to Congress, U.S. DEP'T OF AGRIC., 14 (2009), available at http://www.ers.usda.gov/publication s/ap/ap036/ap036.pdf (citing Phillip Kaufman et. al., Rural poor have less access to supermarkets, large grocery stores, 13(3) RURAL DEV. PERSP. 19 (1999) (“Overall, supermarkets had lower prices - about 10 percent lower nationwide, on average - than other grocery stores such as superettes, convenience stores, and 'mom and pop' stores")).

31. F as in Fat: How Obesity Threatens America's Future, TRUST FOR AMERICA'S HEALTH 20 (2010), available at http://healthyamericans.org/reports/obesity2010 /Obesity2010Report.pdf.

32. The Federal Poverty Level is approximately $\$ 11,170$ for an individual or $\$ 23,050$ for a family of four. 2012 HHS Poverty Guidelines, Dep't of Health and Human Serv., http://aspe.hhs.gov/poverty/12fedreg.pdf (last visited Feb. 20, 2013).

33. Eli Rosenberg, Chart: Fruit and Vegetables Only for the Rich?, THE ATLANTIC WIRE (May 17, 2011) http://www.theatlanticwire.com/national/2011/05/chart-lessfruit-and-less-vegetables-poor/37823/.

34. Kimberly Morland, et al., Supermarkets, Other Food Stores, and Obesity: The Atherosclerosis Risk in Communities Study, 30(4) AM. J. OF Preventive Med. 333, 335 (2006).

35. Shannon N. Zenk et al., Neighborhood Retail Food Environment and Fruit and Vegetable Intake in a Multiethnic Urban Population, 23(4) AM. J. HEALTH PROMOTION 255, 258 (2009). 
Faced with what some have called a "toxic" 36 or "obesogenic"37 food system, in which unhealthy foods are cheap and ubiquitous while their healthy counterparts are comparatively expensive and inaccessible, Americans are consuming far too many unhealthy products and too little healthy food. Our regime of agricultural law broadly encompassing the entire "network of laws and policies that apply to the production, marketing, and sale of agricultural products, i.e., the food we eat, the natural fibers we wear, and increasingly, the bio-fuels that run our vehicles," ${ }^{38}$ props up a food system that produces unhealthy, highlyprocessed foods, rather than supporting the production of foods that are needed for a healthy society. In order to change the relative cost and availability of healthy versus unhealthy foods, thereby reducing the rates of diet-related disease, we must modify our food and agricultural laws and policies to transform the food system and ensure that healthy foods are more affordable and available nationally.

\section{Two Main Responses}

Over the past few years, there has been a more forceful push to overhaul our food system. ${ }^{39}$ Two primary types of reform can improve the food and agricultural system. One avenue focuses on modifying or dismantling the industrial food system in order to decrease the production and consumption of unhealthy products, in hopes that this will eventually drive industry to generate more healthy foods. The other avenue aims to

36. Battle \& Brownell, supra note 5, at 761.

37. Pamela Powell et al., What Is Obesogenic Environment?, U. NEv. CoOP. EXTENSION, 2 (2010), available at http:// www.unce.unr.edu/publications /files/hn/2010/fs1011.pdf (defining an "obesogenic environment" as an environment that promotes weight gain and is not conducive to weight loss); Boyd Swinburn, et al., Dissecting Obesogenic Environments: The Development and Application of a Framework for Identifying and Prioritizing Environmental Interventions for Obesity, 29 PREVENTIVE MeD. 563, 564 (1999).

38. Susan Schneider, What is Agricultural Law?, Remarks Prepared for the Association of American Law Schools 2009 Annual Meeting (Jan. 6-10, 2009), 26 AGRIC. L. UPDATE 1 (2009), available at http://papers.ssrn.com/sol3/ papers.cfm?abstract_id=1331422.

39. See, e.g., Dan Glickman et al., Accelerating Progress in Obesity Prevention: Solving the Weight of the Nation, INST. OF MED., 158 (2012), available at http://www.whatthefolly.com/wp-content/uploads/2012/05/13275.pdf (including as Strategy 2-5: "Broaden the examination and development of U.S. agriculture policy and research to include implications for the American diet"); see generally, Wallinga, supra note 29; Randolph Kline, et al., Beyond Advertising Controls: Influencing JunkFood Marketing and Consumption with Policy Innovations Developed in Tobacco Control, 39 LOY. L.A. L. REV. 603, 613 (2006). 
support increased production of specialty crops, in order to ensure that these healthy products will be more available and affordable, and thus can be consumed more readily. Unfortunately, the second avenue has been largely overlooked. ${ }^{40}$ Part A describes the industrial food system and examines some of the food system modifications advocated by various scholars to reform this system. Part B defines the alternative food system and illustrates the reasons for which more attention should be focused on supporting alternative production, an avenue to improving the food system which has been comparatively overlooked, but which possesses great promise as a method of making healthy foods more abundant and affordable.

\section{A. Option 1: Reforming the Industrial System}

In order to discuss food system reform, the first step is to define what is meant by the "industrial food system" that produces the majority of our food supply. ${ }^{41}$ The term industrial food system generally refers to the network of large farms and agribusinesses that primarily cultivate monocultures of one or two commodity crops, defined as "mass produced article[s] that [are] readily exchanged within the market."42 Industrial producers focus on specialization and product uniformity; ${ }^{43}$ are capitalintensive, reliant on off-farm inputs, including heavy use of various fertilizers and pesticides, generally apply an industrial manufacturing model to their production; ${ }^{44}$ and implement production and distribution chains that are national and global in scale. ${ }^{45}$

40. Jeffrey K. O'Hara, Ensuring the Harvest: Crop Insurance and Credit for a Healthy Farm and Food Future, UNION OF CONCERNED SCIENTISTS, v (April 2012), available at http://www.ucsusa.org/assets/documents/food_and_agriculture/ensuringthe-harvest-full-report.pdf ("One largely untried way in which government policy could encourage Americans to eat more healthy foods is by making it easier for farmers to grow more of them, which would increase their availability to consumers.").

41. See, e.g., Neil D. Hamilton, Feeding Our Future: Six Philosophical Issues Shaping Agricultural Law, 72 NEB. L. REV. 210, 213 (1993) (“American agriculture is changing rapidly-becoming more concentrated, more technically advanced, and more integrated with the input and marketing sectors. In other words, American agriculture is rapidly becoming industrialized.").

42. Foreign Trade: Trade Definitions, U.S. CENSUS BurEaU, http://www. census.gov/foreign-trade/reference/definitions/index.html\#C (last visited Feb. 11, 2013).

43. See, e.g., Mark A. Grey, The Industrial Food Stream and its Alternatives in the United States: An Introduction, 59(2) HuMAN ORG. 143, 144-45 (2000); Eubanks II, supra note 1, at 227; Schneider, supra note 1, at 19.

44. See, e.g., Leo Horrigan, et al., How Sustainable Agriculture Can Address the Environmental and Human Health Harms of Industrial Agriculture, 110(5) ENVTL. 
The industrial food system has achieved great levels of efficiency and, for better or worse, Americans benefit by spending a smaller percentage of their income on food costs than any nation at any time. ${ }^{46}$ But although the American agricultural system is as productive as ever, we are not generating enough of the types of foods, particularly fruits and vegetables, that modern nutrition science and the U.S. Dietary Guidelines for Americans recommend for our population to consume. ${ }^{47}$ Instead, the incredible efficiency of industrial food system production allows for an inundation of excess commodities, which support the manufacturing of cheap, highly-processed food products. ${ }^{48}$ Such food products-processed meats, packaged foods, fast foods, sugar-sweetened beverages, and similar highly-processed items - are the types of foods specifically linked with high rates of obesity and chronic disease. ${ }^{49}$

To make matters worse, these highly-productive, highly-subsidized commodity farms do not grow fruits and vegetables, and are generally prohibited from growing fruits and vegetables on Farm Bill-supported acres. ${ }^{50}$ The Farm Bill has existed for nearly a century, but the modern era

HEALTH PERSP. 445 (2002); Eubanks II, supra note 1, at 251, 269-70; Schneider, supra note 1 .

45. See, e.g., Grey, supra note 43.

46. Michael Pollan, The Food Movement Rising, N.Y. REVIEW OF BoOKS (Aug. 19, 2010), http://www.nybooks.com/articles/archives/2010/jun/10/food-movement-rising/ ?pagination=false (stating that "Americans spend a smaller percentage of their income on food than any people in history-slightly less than 10 percent"); Scott Fields, The Fat of the Land: Do Agricultural Subsidies Foster Poor Health?, 112(14) ENVTL. HEALTH PERSP. A820, A822 (2004) (noting that "[ $t$ ]he proportion of income required to buy food in the United States is among the lowest in the world and has declined steadily since the 1950s").

47. See infra notes 83 - 86 and accompanying text.

48. David Wallinga, et al., Considering the Contribution of U.S. Agricultural Policy to the Obesity Epidemic: Overview and Opportunities, 4 J. HUNGER \& ENVTL. Nutrition 3, 5 (2009); Heather Schoonover \& Mark Muller, Food without Thought: How U.S. Farm Policy Contributes to Obesity, InST. FOR AGRIC. AND Trade POLICY, 4 (2006).

49. Dariush Mozzafarian \& David S. Ludwig, Dietary Guidelines in the $21^{\text {st }}$ Century: A Time for Food, 304(6) J. AM. MED. Ass'N 681 (2010).

50. Planting Flexibility for Fruits \& Vegetables, NAT'L SuSTAINABLE AGRIC. COAL., http://sustainableagriculture.net/publications/grassrootsguide/competitivemarkets-commodity-program-reform/planting-flexibility-for-fruits-vegetables/ (last visited Feb. 14, 2013) (The prohibition does not apply if the producer has a history of producing these crops, but the producer still suffers from a reduction in subsidies payments acre-for-acre); Demcey Johnson et al., Eliminating Fruit and Vegetable Planting Restrictions: How Would Markets Be Affected?, U.S. DEP'T OF AGRIC., ECON. RESEARCH SERV, ERR 30, v (2006), available at http://webarchives.cdlib.org/wayback. 
has seen a concentration of subsidies for the benefit of a small group of commodity crops. ${ }^{51}$ To illustrate, the original Farm Bill, the American Agricultural Act of $1933,{ }^{52}$ aimed to support small farms and invest in a range of crops - over 100 different crops received support in early farm bills. $^{53}$ But as times have changed, so have the subsidies. Between 1997 and 2006, approximately 84 percent of the $\$ 172$ billion dollars of Farm Bill subsidies went to five commodity crops alone: corn, rice, wheat, soybeans, and cotton. ${ }^{54}$ As a result, "farmers are using the majority of American cropland for a few low-nutrient crops solely because these crops are favored by federal agricultural policy." ${ }^{55}$ These subsidies have not been altered in the face of changing nutrition science or the rising rates of obesity and diet-related disease. ${ }^{56}$ Even though the new U.S. Dietary Guidelines for Americans recommend that the majority of one's diet consist of fruits, vegetables, and whole grains, fruit and vegetable producers do not receive any direct subsidies. ${ }^{57}$ By contrast, over $70 \%$ of farm payments went to corn, wheat, rice, soybeans, and feedgrains - all of which are used to produce sweeteners, oils, and meat, even though the Dietary Guidelines encourage moderation for all of those products-while another 26.2 percent of the subsidies went to cotton, rather than to healthy food items. ${ }^{58}$ These subsidies make commodity crops, and the food

public/UERS_ag_1/20110903171556/http://ers.usda.gov/publications/err30/err30_high res.pdf.

51. The USDA defines "covered commodity" or "program commodity" as "Commodities for which Federal support programs are available to producers, including wheat, corn, barley, grain sorghum, oats, upland cotton, medium and long grain rice, oilseeds, and pulse crops (small and large chickpeas, dry beans and lentils). Programs for peanuts are separate in the 2002 and 2008 Farm Acts but are similar to those for covered commodities." Farm and Commodity Policy, U.S. DEP'T OF AGRIC., ECON. RESEARCH SERV., http://www.ers.usda.gov/topics/farm-economy/farmcommodity- policy /glossary.aspx\#Considered planted (last visited Feb. 17, 2013).

52. Agricultural Adjustment Act, Pub. L. No. 73-10, 48 Stat. 31, 1933.

53. Eubanks II, supra note 1, at 221.

54. Id. at 227.

55. Id. at 280 .

56. Note that the draft Farm Bill that passed the Senate and was discussed in the House in 2012 would have eliminated direct subsidy payments, but both versions still maintained support for the same commodity crops via subsidized crop insurance and a range of other programs. See Agriculture Reform, Food and Jobs Act of 2012, S. 3240, 112th Cong. (2012); Federal Agriculture Reform and Risk Management Act of 2012, H.R. 6083, 112th Cong. (2012).

57. Randy Schnepf, Measuring Equity in Farm Support Levels, CONG. RESEARCH SERV., RL34053, 4 (July 20, 2010), available at http://assets.opencrs.com/rpts/ RL34053_20100720.pdf.

58. Id. at 6, Fig. 3. According to one estimate, fruits and vegetables only receive 2 percent of federal agricultural subsidies; 15 percent of agricultural subsidies went 
products that use these crops as inputs, artificially cheap and affordable, thus steering the American diet towards those foods. ${ }^{59}$

With a system that is so imbalanced, and with rates of obesity and diet-related disease climbing as high as they have, it is not hard to see why many scholars have called for reforms to force the industrial food system to produce more nutritious foods or reduce the ability of consumers to purchase unhealthy ones. These scholars have suggested a range of approaches, such as: creating barriers to the consumption of unhealthy foods using taxes or bans; ${ }^{60}$ restricting the ability of corporations to advertise unhealthy foods, particularly to vulnerable populations such as children $;{ }^{61}$ using class action litigation to force industry-wide reform; ${ }^{62}$ and of course reducing or eliminating Farm Bill subsidies for commodity crops,

towards crops that become sweeteners, starches, oil, and alcohol; and 63 percent went toward crops grown solely for feed for livestock. Agriculture and Health Policies in Conflict: How Food Subsidies Tax Our Health, Agricultural Policies versus Health Policies, Physicians Committee FOR Responsible Med. (April 2011), http://www.pcrm.org/health/reports/agriculture-and-health-policies-ag-versus-health.

59. See, e.g., Eubanks II, supra note 1, at 280-81; Jackson et al., supra note 14, at 393-400. But see Julian M. Alston, et al., Impact of Agricultural Policies on Caloric Consumption, Trends in Endocrinology and Metabolism, SCIENCE DIRECT (Jan. 2013) (finding that agricultural policies have had mixed effects on prices of commodities, negligible effects on consumer prices, and negligible effects on consumption and obesity); Sonia M. Grandi \& Caroline Franck, Agricultural Subsidies: Are They a Contributing Factor to the American Obesity Epidemic?, 172(22) J. AM. MED. Ass'N 1754 (Dec. 2012) (arguing that the extent of the Farm Bill impact on the obesity epidemic is unclear).

60. See, e.g., Lawrence O. Gostin et al., Assessing Laws and Legal Authorities for Obesity Prevention and Control, 37 J.L. MED. \& ETHICs 28, 31 (2009); Kline et al., supra note 39, at 613; Tatiana Andreyeva, et al., Estimating the Potential of Taxes on Sugar-sweetened Beverages to Reduce Consumption and Generate Revenue, 52 PREVENTIVE MED. 413 (2011).

61. See, e.g., J. Michael McGinnis, et al., Food Marketing to Children and Youth: Threat or Opportunity? Inst. OF MED., COMM. ON FOOD MKTG. AND THE DIETS OF CHILDREN AND YoUTH (2005), available at http://www.iom.edu/Reports/2005/FoodMarketing-to-Children-and-Youth-Threat-or-Opportunity.aspx; Gostin et al., supra note 60 at 31; Lauren Kaplin, A National Strategy to Combat the Childhood Obesity Epidemic, 15 U.C. DAVIS J. JuV. L. \& PoL'Y 347, 393-99 (2011); Jennifer L. Pomeranz, Television Food Marketing to Children Revisited: The Federal Trade Commission Has the Constitutional and Statutory Authority to Regulate, 38 J. L. MED. \& ETHICS 98 (2010).

62. See, e.g., Margaret Sova McCabe, The Battle of the Bulge: Evaluating Law As A Weapon Against Obesity, 3 J. FoOD L. \& POL'Y 135, 138 (2007) (noting that, "[1]itigation, while an undesirable substitute for public health policy-making, has actually made the greatest strides in bringing change to food choices in America"); Kline et al., supra note 39, at 613. 
as a means of driving down the overproduction of these crops. ${ }^{63}$ Despite the true need for improvement of the industrial food system, these reform efforts are stalled, due primarily to a lack of political will. For example, despite acknowledgement of the obesity epidemic, proposals in the 2008 Farm Bill reauthorization to eliminate or amend the prohibition on fruit and vegetable production on commodity acres were defeated. ${ }^{64}$

Further, some of these reforms may not be sufficient to improve the food system. Banning unhealthy foods has been met with considerable backlash, ${ }^{65}$ as have efforts to restrict marketing ${ }^{66}$ or require menu

63. See, e.g., Eubanks II, supra note 1, at 297-99; Wallinga, supra note 29, at 40810; Anna O'Connor, Fence Row to Fence Row: An Examination of Federal Commodity Subsidies, 21 KAN. J. L. \& PUB. POL'Y 432, 447 (2012).

64. Planting Flexibility for Fruits \& Vegetables, NAT'L SUSTAINABLE AGRIC. COAL., http://sustainableagriculture.net/publications/grassrootsguide/competitivemarkets-commodity-program-reform/planting-flexibility-for-fruits-vegetables/ (last visited Feb. 20, 2013). However, both the Senate and House draft versions of the 2012 Farm Bill include language that would repeal direct payments to farms growing commodity crops, and thus would in effect eliminate the restrictions on fruit and vegetable production. Joseph V. Balagtas, et al., Working Paper: Impact of the Fruit and Vegetable Planting Restriction on Crop Allocation in the United States, CORNELL Univ., Charles H. Dyson Sch. OF ApPlied Econ. AND MGMT., 4-5 (Nov. 2012), available at http://dyson.cornell.edu/research/researchpdf/wp/2012/Cornell-Dysonwp1214.pdf; see Agriculture Reform, Food and Jobs Act of 2012, S. 3240, 112th Cong. $\S 1101$ (a) (2012); Federal Agriculture Reform and Risk Management Act of 2012, H.R. 6083, 112th Cong. § 1101(a) (2012) (repealing Sections 1103 and 1303 of the Food, Conservation, and Energy Act of 2008 (7 U.S.C. $\$ 8713,8753$ (2007)). But note that because the subsidized crop insurance programs will still primarily support commodity crops, disincentives to specialty crop production will remain.

65. A recent move to ban the sale of sugar sweetened beverages above 16 ounces in restaurants, delis, movie theaters, and other vendors in New York City was met with much resistance and anger from both industry and consumers. N.Y.C. Health Code $\S$ 81.53 (2012); Michael M. Grynbaum \& Marjorie Connelly, 60\% in City Oppose Bloomberg's Soda Ban, Poll Finds, N.Y. TIMES (Aug. 22, 2012), http://www.nytimes.com/2012/08/23/nyregion/most-new-yorkers-oppose-bloombergssoda-ban.html. A New York court subsequently struck down the portion cap rule, finding both that the Board of Health did not have the authority to promulgate the rule and that the rule was arbitrary and capricious. See, New York Statewide Coalition of Hispanic Chambers of Commerce v. New York City Department of Health and Mental Hygiene, 653584-2012, New York State Supreme Court, New York County (Manhattan); Michael Howard Saul, Judge Cans Soda Ban, The Wall STReET JOURNAL (March 11, 2013), http://online.wsj.com/ article/SB100014241 27887323826704578354543929974394.html.

66. As an example, federal efforts to create voluntary principles to guide industry in what foods it should market to children was derailed after industry pushed back. See infra notes 94 - 96 and accompanying text. 
labeling. ${ }^{67}$ Impact litigation is costly and incredibly time-consuming, and its outcomes are uncertain. ${ }^{68}$ More importantly, as the next sections will argue, these types of reforms alone will not necessarily lead to the provision of healthy foods in the immediate future and thus do not offer a complete solution unless they are paired with efforts explicitly aimed at increasing healthy food production. While scholars and policymakers should continue their efforts to reform the industrial food system, this article argues that those reforms will not be enough, and a focus on supporting the alternative food producers who can provide healthy foods is an essential other half of the policy equation.

\section{B. Option 2: Improving Viability of the Alternative Food System}

In contrast to the path to reform that focuses on transforming or dismantling the industrial food system, there is the option of supporting the alternative food system in order to increase production-and thus availability — of fruits, vegetables, and other healthy options. In opposition to the industrial food system, the alternative food system is made up of a range of small or mid-size specialty crop producers. This article defines the "alternative food system" as consisting of farms that:

- are small (approximately100 acres or under, selling less than $\$ 250,000$ per year) ${ }^{69}$ or mid-size (100-500

67. See, e.g., New York State Rest. Ass'n v New York City Bd. of Health, 509 F Supp 2d 351, 353 (S.D.N.Y. 2007); New York State Rest. Ass'n v New York City Bd. of Health, 556 F3d 114, 118 (2d Cir. 2009); Thomas A. Farley et al., New York City's Fight Over Calorie Labeling, 28(6) HEALTH AFFAIRS 1098 (Oct. 2009).

68. See, e.g., McCabe, supra note 62, at 148-49 (noting that "Pelman [v. McDonald's Corp.] also indicates how costly food litigation can be in terms of judicial resources, attorneys fees, and media attention"); Kline et al., supra note 39, at 632 (noting that "barriers to a litigation approach exist, including potential difficulties forming a valid claim and the extreme cost of litigating against a powerful industry").

69. Robert A. Hoppe, et al., Small Farms in the United States: Persistence Under Pressure, U.S. DEPT OF AGRIC., ECON. RESEARCH SERV. (Feb. 2010), http://www.ers.usda.gov/media/147007/eib63_1_.pdf (defining small farms as those with annual sales under \$250,000); 2007 Census of Agriculture: Small Farms, U.S. DePT OF AgriC., NAT'L AgriC. STATISTICs SERVICE, http://www.agcensus.usda.gov/ Publications/2007/Online_Highlights/Fact_Sheets/Farm_Numbers/small_farm.pdf (defining small farms as farms with $\$ 250,000$ or less in sales of agricultural commodities); History and Philosophy, SMALl FARM TODAY Magazine, http://www.smallfarmtoday.com/ (last visited Feb. 20, 2013) (defining “"small farm' as a farm that is 179 acres or less in size, or earns $\$ 50,000$ or less in gross income per year. This definition is based on data from the Bureau of Census and USDA Census (1987-1997), results of the Small Farm Today ${ }^{\circledR}$ magazine survey of readers (19931998), and data from the New Farm Committee of the University of Missouri and Lincoln University (1989)”); 7 U.S.C.A. § 2666(c) (2012) (““[S]mall farm” means any 
acres and selling from $\$ 50,000-\$ 500,000$ per year) ${ }^{70}$

- operate diverse practices to produce a range of different specialty crops or a combination of specialty crops and animal-based products; ${ }^{71}$ and

- primarily sell their products locally and regionally through either direct marketing to consumers or via smaller, regional distribution chains. ${ }^{72}$

Enhancing the alternative food system is essential to increase our supply of fruits and vegetables because these alternative food producers, if given more resources and support, would have the capacity to produce more healthy food products right away. This is not to say that specialty crop production on large-scale farms should be discounted. Large-scale production of fruits and vegetables could go even further towards making such products more available for Americans. To be sure, the fruit and vegetable industry in the United States has also become quite industrialized, particularly in certain regions of the country and in the production of particular crops, and with some negative consequences. ${ }^{73}$ But because the majority of specialty crop production takes place on small or

farm (1) producing family net income from all sources (farm and nonfarm) below the median nonmetropolitan income of the State; (2) operated by a family dependent on farming for a significant though not necessarily a majority of its income; and (3) on which family members provide most of the labor and management.").

70. Characterizing Ag of the Middle and Values-Based Food Supply Chains, AGRIC. OF THE MIDDLE (Jan. 2012), http://www.agofthemiddle.org/archives/2012/01/ characterizing.html\#more (defining mid-size farms as those that are "in the $\$ 50,000$ $\$ 500,000$ range of gross sales); Fred Kirschenmann et al., Why Worry About the Agriculture of the Middle?, AGRIC. OF THE MIDDLE 1 (2004), http://www.agofthemiddle.org/papers/whitepaper2.pdf (last visited Feb. 19, 2013) (noting that "the bulk of these farms have gross annual sales between $\$ 100,000$ and \$250,000”); but see Robert A. Hoppe \& David E. Banker, Structure and Finances of U.S. Farms, Family Farm Report, 2010 Edition, U.S. DEPT OF AGRIC., ECON. RESEARCH SERVICE, EIB 66, iv (2010), available at http://www.ers.usda.gov/media/184479/eib66_1_.pdf (calling farms with sales from $\$ 250,000$ - $\$ 499,999$ "large farms" and those above $\$ 500,000$ "very large farms").

71. This would include farms that are similar to the "healthy food farms" defined by the Union of Concerned Scientists as "farms that grow fruits, vegetables, and other healthy crops rather than crops such as corn and soybeans that are primary ingredients in processed foods." O'Hara, supra note 40, at v.

72. Kirschenmann et al., supra note 70.

73. See, e.g. BARRY ESATABROOK, TOMATOLAND: How MODERN INDUSTRIAL Agriculture Destroyed Our Most Alluring Fruit (Andrews McMeel Publishing LLC, 2011). 
mid-size farms, ${ }^{74}$ this article will focus on those growers, and will recommend ways to increase the production of specialty crops by ramping up their operations. Supporting small and mid-scale specialty crop producers around the country, rather than boosting large-scale production in a few locations, can also increase the affordability of healthy foods by reducing shipping costs and decreasing consumer prices. Though not discussed in detail in this article, supporting these local and regional food producers can also address other food system concerns, for example, by improving environmental sustainability and augmenting local economic development. ${ }^{75}$

Many scholars have written about ways to reform the industrial food system, ${ }^{76}$ and others have discussed reasons to support the local food movement, ${ }^{77}$ but few have written about supporting the alternative food

74. See, e.g., 2007 Census of Agriculture: Vegetables, Potatoes, and Melons, U.S. DEP'T OF AGRIC., NAT'L AGRIC. STATISTICS SERV., http://www.agcensus.usda.gov/ Publications/2007/Online_Highlights/Fact_Sheets/Production/vpm.pdf (last modified Jan. 30, 2012) (noting that while the average size of U.S. farms is 418 acres, the average size for a vegetable, potato and melon farm is 228 acres). Indeed, with the exception of large-scale specialty crop production in states like Florida and California, most specialty crops are grown on a smaller scale than commodity crops. See Nicholas R. Johnson \& A. Bryan Endres, Small Producers, Big Hurdles: Barriers Facing Producers of “Local Foods”, 33 HAMLINE J. PUB. L. \& POL'y 49, 52 (2011) (noting that, in 2007 California produced 84 percent of the head lettuce grown for U.S. consumption).

75. See generally Market Forces: Creating Jobs through Public Investment in Local and Regional Food Systems, UnION OF CONCERnED ScIENTISTS (Aug. 2011), http://www.ucsusa.org/food_and_agriculture/solutions/expand-healthy-food-

access/market-forces.html; see Rich Pirog, et al., Food, Fuel and Freeways: An Iowa Perspective on How Far Food Travels, Fuel Usage, and Greenhouse Gas Emissions, LEOPOLD CTR. FOR SUSTAINABLE AGRIC., 1-2 (2001), http://www.leopold.iastate. edu/pubs/staff/ppp/food_ mil.pdf ("The conventional system used 4 to 17 times more fuel than the Iowa-based regional and local systems, depending on the system and truck type. The same conventional system released from 5 to 17 times more $\mathrm{CO}_{2}$ from the burning of this fuel than the Iowa-based regional and local systems.").

76. See supra notes $60-63$ and accompanying text.

77. For example, scholarship has analyzed the benefits of the local food movement through the lenses of creating opportunities for local economic development, see Neil D. Hamilton, Rural Lands and Rural Livelihoods: Using Land and Natural Resources to Revitalize Rural America, 13 DRAKE J. AgRIC. L. 179, 184 (2008); Kathryn A. Peters, Creating A Sustainable Urban Agriculture Revolution, 25 J. ENVTL. L. \& LITIG. 203, 223 (2010) (noting that urban agriculture "promotes economic growth by allowing urban residents to supplement their income if they distribute their produce"). For more on reducing harmful environmental impacts, see Carmen G. Gonzalez, Climate Change, Food Security, and Agrobiodiversity: Toward A Just, Resilient, and Sustainable Food System, 22 FordHAM ENVTL. L. REV. 493 (2011); Peters, supra note 76, at 220 (arguing that "a sustainable urban agricultural system would minimize the 
system as a means to improve public health outcomes. ${ }^{78}$ More attention and energy must be focused on fostering the alternative system for a range of reasons discussed below. Despite the array of programs targeted at increasing demand for healthy foods, we currently direct very little of our production capacity toward specialty crops, and merely reforming the industrial system will not ensure the production of substantially more healthy foods in the short-term. Thus, we must concentrate on the alternative food system as a viable solution to our short-term, and possibly long-term, food and nutrition needs.

1. Demand for healthy food is increasing, yet too little of our current production focuses on specialty crops

In response to the obesity epidemic, various U.S. policies and programs are already working to create more demand for healthy foods, but our supply of such food products falls short. While "governments can create powerful incentives for healthy eating and exercise," access to the right foods, such governmental programs will not achieve success. As examples of this movement to shift demand, the new 2011 USDA MyPlate - based on the 2010 Dietary Guidelines for Americansrecommends that people eat half a plate of fruits and vegetables at every meal ${ }^{80}$ schools utilizing National School Lunch or National School Breakfast Program funds are required to serve more fruits and vegetables

impacts of food production on the planet"). For more on helping consumers to be closer to their food sources, see, e.g., Johnson \& Endres, supra note 73, at 56; Derrick Braaten \& Marne Coit, Legal Issues in Local Food Systems, 15 DRAKE J. AGRIC. L. 9, $10(2010))$.

78. Local foods may not be healthier than the same foods produced a long distance from the point of consumption, Johnson \& Endres, supra note 73, at 89 (noting that "research has not conclusively established whether local food is in fact healthier than food that comes from far away"); Gabrielle O'Kane, What is the real cost of our food? Implications for the environment, society and public health nutrition, 15(2) PUB. HEALTH NutRITION 268, 274 (2012) (noting that "researchers need to more clearly establish the links between use of local food systems and better eating habits and reductions in obesity and chronic disease"). However, "[p]romoting local food production and direct-farm marketing can help improve the nutritional health of the nation," because local and regional systems are the primary sales routes for alternative food producers. Neil D. Hamilton, Moving Toward Food Democracy: Better Food, New Farmers, and the Myth of Feeding the World, 16 DRAKE J. AGRIC. L. 117, 124 (2011). Thus, supporting local food systems bolsters the alternative food system and will ultimately improve the accessibility and affordability of healthy food options.

79. Gostin et al., supra note 60, at 31 .

80. ChooseMyPlate.gov, U.S. DEPT OF AGRIC., www.choosemyplate.gov (last visited Feb. 20, 2013). 
than ever before ${ }^{81}$ and the food package for the Supplemental Nutrition Program for Women, Infants, and Children (WIC) now demands that more fruits and vegetables be available to program participants at all WIC vendor sites. $^{82}$

Unfortunately, these attempts to address the obesity epidemic have primarily focused on changing consumer behaviors rather than looking at "upstream determinants," namely, the food supply. ${ }^{83}$ Despite the push to alter demand, our current agricultural outputs do not line up with the foods recommended or even required under the programs described above. The industrial food system has dramatically increased its efficiency in order to produce a surplus of calories, but the production of healthy foods is still inadequate. In 2009, the U.S. devoted less than 2 percent of its cropland to production of fruits and vegetables. ${ }^{84}$ The United States currently produces 24 percent fewer servings of vegetables per person than is recommended in the Dietary Guidelines. ${ }^{85}$ According to the USDA, in order for the U.S. to produce the amount of fruits and vegetables that the Dietary Guidelines recommend for consumption by Americans, we would have to add a combined 13 million new acres of fruit and vegetable production. ${ }^{86}$ Without changing our policies to support food producers who are willing to generate more specialty crops, we will not have enough healthy food available to meet the Dietary Guidelines recommendations and other U.S. food program requirements, undermining the impact of efforts to combat obesity and chronic illness by improving diets.

81. 7 C.F.R. $\$ 210.10$ (2012).

82. Special Supplemental Nutrition Program for Women, Infants, and Children (WIC): Revisions in the WIC Food

Packages, 75 Fed. Reg. 243, 79484 (Dec. 20, 2010) (codified at 7 C.F.R. § 246.10).

83. Jackson et al., supra note 14, at 395.

84. O'Hara, supra note 40, at 1.

85. Jean C. Buzby, et al., Possible Implications for U.S. Agriculture from Adoption of Select Dietary Guidelines, U.S. DEP'T OF AGRIC., ECON. RES. SERV., ERR 31 (2006), available at http://www.ers.usda.gov/media/860109/err31_002.pdf. Based on current U.S. production, only 36 percent of the recommended servings of dark green vegetables are available, and only 35 percent of the orange vegetables and 19 percent of the recommended legumes are available. Id. For dark-green leafy greens, availability would have to increase from 6,098 to 16,767 (million pounds) to meet the Dietary Guidelines. For orange vegetables, availability would have to increase from 6,077 to 17,171 (million pounds) to meet the Dietary Guidelines. For legumes, availability would have to increase from 3,348 to 17,796 (million pounds) to meet the Dietary Guidelines. Id. at table 6.

86. See id. (noting that fruit acreage would need to increase from 3.5 million to 7.6 million acres and vegetable acreage would need to increase from 6.48 million acres to 15.35 million acres); see also Patricia L. Farnese, Remembering the Farmer in the Agriculture Policy and Obesity Debate, 65 FoOD \& DRUG L.J. 391, 398 (2010). 
Some might argue that we could simply increase imports of fruits and vegetables to meet the U.S. demand for these foods, but this has obvious disadvantages, including increased fuel and shipping costs, food safety concerns, and implications for national security. ${ }^{87}$ As point of fact, the Food and Drug Administration (FDA) has the resources to inspect less than 2 percent of all imported fish, vegetables, and fruit. ${ }^{88}$ Instead of relying on international markets, the U.S. should focus on increasing domestic production of the foods that are necessary for a healthy diet by fostering the alternative food system.

2. Reforming the industrial food system alone will not ensure increased production of healthy foods on the timetable needed

Although the industrial food system reforms called for by many are essential, by themselves they are not sufficient. Public health outcomes will not improve unless there is an immediate increase in the availability of healthy food. Simply eliminating Farm Bill subsidies "cannot be viewed as a quick fix for overproduction and low prices" of commodity crops, as it would drive away many farmers and discourage new farmers from entering the field, including the farmers needed to grow the crops that a healthier diet requires. ${ }^{89}$ Eliminating subsidies would likely reduce agricultural production in the short-term, causing food prices to rise. ${ }^{90}$ Furthermore, farmers have invested in the machinery, training, and farm inputs needed for the production of commodity crops, as a result of decades of Farm Bill

87. Wallinga, supra note 29, at 407; A. Bryan Endres \& Jody M. Endres, Homeland Security Planning: What Victory Gardens and Fidel Castro Can Teach Us in Preparing for Food Crises in the United States, 64 FoOD \& DRUG L. J. 405, 408 (2009) (noting that "[r]ising food and fuels costs, coupled with dramatic food safety lapses" are pushing policymakers to reconsider the long-term health of an industrial food system that relies on food imported from abroad or shipped long distances domestically); Trexler, supra note 3, at 330 ("Some argue that our regulatory agencies will never have enough resources to meet the [food safety] demands of increasing imports.").

88. Brad Racino, Flood of Food Imported to U.S., But Only 2 Percent Inspected, NBCNEwS.COM (Oct. 3, 2011), http://www.msnbc.msn.com/id/44701433/ns/healthfood_safety/t/flood-food-imported-us-only-percent-inspected/\#.UPMp5uQ0WSo;

Andrew Bridges, Imported Food Rarely Inspected, USA TODAY (Apr. 16, 2007) http://www.usatoday.com/news/nation/2007-04-16-imported-food_N.htm.

89. Wallinga, supra note 29, at 406-07; William S. Eubanks II, The Sustainable Farm Bill: A Proposal for Permanent Environmental Change, 39 ENVTL. L. REP. 10493, 10506 (2009) (noting that "the vast subsidy infrastructure currently embedded in the Farm Bill would be difficult to pull out from under the feet of farmers that depend on those subsidies to survive").

90. See Wallinga, supra note 29, at 406-07. 
incentives tied to those crops. Simple elimination of those incentives may not result in a quick change in production choices, as path dependence will inevitably lead many farmers to continue producing the same crops to which they have grown accustomed. ${ }^{91}$ Though food producers may be incentivized to increase specialty crop production if subsidies were shifted to healthier crops instead of being eliminated, something this author would support, merely removing the current subsidies will not address the oversupply of cheap, unhealthy foods or make healthy foods more readily available, at least in the immediate future. ${ }^{92}$ Similarly, other food system reforms, such as taxes and bans, marketing restrictions, or impact litigation will not make healthy foods more available and accessible at once. While they may lead to a series of changes in the food industry over time, turning around the industrial food system quickly may ultimately be impossible; such changes are, therefore, properly viewed as long-range plans, not a rapid path to increase access to healthier foods.

Along the same lines, reform of the industrial food system will not be able to address immediate demand for healthy foods because the U.S. government has not demonstrated the political will to implement food system reforms on the scale that would be necessary to galvanize extensive changes in production. The lack of resolution, particularly at the federal level, has been apparent in various federal actions over the past few years. For example, with regard to subsidy reform, though the 2012 Farm Bill drafts that were put forward in the House and passed in the Senate would have eliminated direct subsidy payments, both versions still maintained support for the same commodity crops via subsidized crop insurance. ${ }^{93} \mathrm{~A}$ similar, example occurred in the context of the Interagency Working Group on Food Marketed to Children, created by Congress in 2009 to address

91. Oona A. Hathaway, Path Dependence in the Law: The Course and Pattern of Legal Change in A Common Law System, 86 IowA L. REV. 601, 613 (2001) (describing path dependence that is based on increasing returns and noting that under an increasing returns dynamic, "each step in one direction makes additional steps in that same direction more likely"). Thank you to Daniel Bowman Simon for drawing my attention to the concept of path dependence in this context.

92. See Wallinga, supra note 29, at 406-07.

93. See Agriculture Reform, Food and Jobs Act of 2012, S. 3240, 112th Cong. (2012); Federal Agriculture Reform and Risk Management Act of 2012, H.R. 6083, 112th Cong. (2012). But note that no new Farm Bill was passed in 2012, and instead the 2013 fiscal cliff legislation merely continued the 2008 Farm Bill until September 30, 2013 with all of its direct subsidies for the same commodity crops. Congress Includes Awful 2008 Farm Bill Extension in Fiscal Cliff Deal, NATL Sustainable AGRIC. COAL. (Jan. 3, 2013) http://sustainableagriculture.net/blog/farm-bill-extensionfiscal-cliff/. 
propose restrictions on food marketing. ${ }^{94}$ Made up of representatives of the Federal Trade Commission, Centers for Disease Control and Prevention, FDA, and USDA, this working group attempted to create a set of voluntary principles to assist industry self-regulation by "guide[ing] the industry in determining which foods would be appropriate and desirable to market to children to encourage a healthful diet and which foods industry should voluntarily refrain from marketing to children." $" 95$ These voluntary principles were inherently weak, as such non-binding guidance does not have the force of law. Even so, industry pushed back and the entire process came to an abrupt halt after Congress required the Working Group to conduct a cost-benefit analysis of its voluntary principles. ${ }^{96}$

These examples are two among many recent illustrations of the lack of political will, at least at the federal level, to significantly reform the industrial food system. Yet unless significant new costs are imposed on the industrial food system through the legal regime, the industrial farms that produce commodity crops will not be interested in switching to production of specialty crops. With no sign that the necessary changes to the current system will take place any time soon, the focus must be on investment in an alternative food system that thrives in spite of the current food landscape and supplies the foods needed to improve our public health.

3. Supporting the alternative food system is necessary to the goal of making healthy foods more available and affordable

In order to increase consumption of fresh fruits and vegetables, which is central to the goal of obesity reduction, we must increase the availability of fruits and vegetables that ultimately reach the consumer at an affordable price. ${ }^{97}$ Studies have shown that people will choose healthier options when they are more readily available ${ }^{98}$ and when they are more affordable. ${ }^{99}$

94. Omnibus Appropriations Act, 2009 (H.R. 1105, Pub.L. 111-8), Financial Services and General Government, Explanatory Statement, Title V, Independent Agencies, 983-84.

95. Preliminary Proposed Nutrition Principles to Guide Industry Self-Regulatory Efforts, Request for Comments, INTERAGENCY WORKING GRP. ON FOOD MARKETED TO CHILDREN, 5 (2011), http://www.ftc.gov/os/2011/04/110428foodmarketproposedguide. pdf (citing Omnibus Appropriations Act, 2009 (H.R. 1105, Pub.L. 111-8), Financial Services and General Government, Explanatory Statement, Title V, Independent Agencies, 983-84).

96. Consolidated Appropriations Act of 2012, § 626 (H.R. 2055, Pub. L. 112-74). Note that the Federal Trade Commission released a follow up report in December 2012. 97. Farnese, supra note 86, at 398-99.

98. See, e.g., Kimberly Morland, et al., The Contextual Effect of the Local Food Environment on Residents' Diets: The Atherosclerosis Risk in Communities Study, 
Unfortunately, some discussions about the alternative food system dismiss healthy, local, organic, or sustainable foods as "costly" options that can only meet the needs of middle and upper class consumers. ${ }^{100}$ But if we invest in the creation of a viable alternative food system, these foods can be made both more available and more affordable. Such changes can take place more quickly than those made by reforming the industrial food system. In particular, the types of policy changes needed to support the alternative food system may also be more politically feasible than some of the other food system reforms described above. Because for the foreseeable future, the bulk of fruit and vegetable production will continue to take place on small or mid-scale farms, resources should be deployed to reduce costs of production on these farms so that consumer prices of these healthy foods will decrease.

For the reasons illustrated in this section, supporting the alternative food system is equally as vital, if not even more essential, as reforming the industrial food system. Only supporting the alternative system promises to increase access to healthy foods in the short term. Further, supporting the alternative food system can also help us to develop a more sustainable, resilient, and safe food system in the long term. ${ }^{101}$ The remainder of this article discusses barriers to the expansion of the alternative food system that produces healthier crops and asserts that the legal profession should play a key role in shaping a legal landscape conducive to healthy food production.

92(11) AM. J. OF PuB. HeAlth 1761 (Nov. 2002) (finding that local food environments and food availability impact diet and consumption).

99. See Simone A. French, Pricing Effects on Food Choices, 133 J. NUTRITION 841S (2003) (finding that "price reductions are an effective strategy to increase the purchase of more healthful foods in community-based settings such as work sites and schools").

100. See, e.g., Jerry Hagstrom, Senators' Letter Critical of 'Know Your Farmer' Program, AGWEEK, May 17, 2010, http://www.agweek.com/event/article/id/16388/; Roger Cohen, The Organic Fable, N.Y. Times (Sept. 6, 2012) http://www.nytimes.com/2012/09/07/opinion/roger-cohen-the-organic-fable.html;

Robert Paarlberg, Attention Whole Foods Shoppers, ForEIGNPOLICY.COM (May/June 2010),

http://www.foreignpolicy.com/articles/2010/04/26/attention_whole_foods_shoppers?pa ge=0,0; Steve Sexton, The Inefficiency of Local Food, FrEAKONOMICS.COM (Nov. 14, 2011), http://www.freakonomics.com/2011/11/14/the-inefficiency-of-local-food/; Mehmet Oz, Give (Frozen) Peas A Chance-And Carrots Too, TIME MAG. (Dec. 3, 2012).

101. See Endres \& Endres, supra note 87, at 408-09. 


\section{Barriers to the Alternative Food System}

Any alternative to our current industrial food system suffers from great disadvantages in terms of financial support, infrastructure, and a legal and policy regime that favors large-scale agribusinesses. For these reasons, as more of our food production has consolidated via the industrial food system, the number of small and medium-sized farms has declined. ${ }^{102}$ The farmer population is aging. ${ }^{103}$ New farmers are not entering the field fast enough, and a range of barriers stand in the way of their success. ${ }^{104}$ Yet we should not forget that farmers are needed to produce healthy foods, and for specialty crop farms to remain viable, they need to have the opportunity to produce real profits. ${ }^{105}$

Barriers to the success of the alternative food system can be broken into three main categories, described below. The first category includes federal and state programs and policies that either fail to support specialty crop production or disadvantage small or mid-size producers by including explicit preferences for large farms and corporations. The second category consists of barriers posed by a legal and regulatory regime that does not utilize risk- or scale-appropriate methods of regulation and thus unfairly penalizes small producers. In addition to these two main categories of barriers to small-scale producers, the third category includes a range of hurdles that acutely impact the mid-size producers that make up what is known as the "agriculture of the middle." Agriculture of the middle often suffers disproportionately and thus has seen the largest decline in size, despite the promise that this class of producers presents for the creation of a viable alternative food system.

\section{A. Programmatic and Policy Barriers to Small Food Producers}

Federal and state food and agricultural programs currently do not protect or promote specialty crop production or the alternative food system.

102. Eubanks II, supra note 1, at 228-33.

103. Megan Mills-Novoa, Sustaining Family Farming Through Mentoring: A Toolkit for National Family Farm Coalition Members, NAT'L FAMILY FARM COAL. 6-7 (Jan. 2011), available at http://www.nffc.net/Issues/Local\%20Food/NFFC_Mentoring_ Report2011.final.pdf (noting that in 1970, the average age of a farmer was 50, but as of 2007, it was 57, with 25 percent of farmers over age 65).

104. Neil D. Hamilton, Farms, Food, and the Future: Legal Issues and Fifteen Years of the "New Agriculture", 26 J. ENVTL. L. \& LiTIG. 1, 5 (2011) ("The aging farm population, the concentration of land with older owners, [and] transfers to off-farm or often out-of-state heirs," all present challenges.).

105. Neil D. Hamilton, America's New Agrarians: Policy Opportunities and Legal Innovations to Support New Farmers, 22 FORDHAM ENVTL. L. REV. 523, 548 (2011). 
As a threshold matter, specialty crop producers certainly do not receive sufficient economic support. Specialty crops received only $\$ 55$ million in subsidies in 2012, delivered to states via the Specialty Crop Block Grant Program funded through the Farm Bill. ${ }^{106}$ To put that in perspective, USDA spent $\$ 4.9$ billion total on farm subsidies in $2011 .{ }^{107}$ Unlike the commodity crop subsidies and supports, which are consistent and reliable payments made directly to individual growers by the USDA, Specialty Crop Block Grants are limited to annual allotments to each state and may only go to support a handful of specific crops or specific producers in a state in a given year. Many scholars have argued that instead of eliminating the Farm Bill subsidies completely, Congress should shift a fair portion of these subsidies to farmers implementing sustainable agricultural methods or producing healthier foods. ${ }^{108}$ Such a shift will surely be necessary to increase specialty crop production on larger farms because, as noted above, path dependence will encourage commodity crop producers to continue to produce the same crops in the future, unless a countervailing set of incentives encourage them to produce alternatives. But specialty crop supports should also be made available to assist small and mid-size producers in surmounting some of the other barriers that stand in the way of their success, as additional funds could support the creation of new infrastructure and systems to get their food to market. For example, land access, another critical barrier for farmers, ${ }^{109}$ could be addressed by increasing access to capital for specialty crop producers.

In addition to the dearth of specialty crop subsidies, specialty crop producers are excluded from other types of key agricultural support programs. Unfortunately, "the traditional system and tools for serving the needs of agriculture, such as Farm Service Agency loans, farm organizations, and extension programs," are not designed for small or mid-

106. Definition of Specialty Crops, U.S. DeP'T OF AGRIC., AGRIC. MKTG. SERV., http://www.ams.usda.gov/AMSv1.0/scbgpdefinitions (last visited Feb. 16, 2013); 2011 Specialty Crop Block Grants Announced, NAT'L SUSTAINABLE Agric. COAL., http://sustainableagriculture.net/blog/2011-scbg/ (last visited Feb. 16, 2013); California Agriculture Leads the Nation in Funding for Specialty Crops, CAL. DEP'T OF FOOD AND AGRIC. (Oct. 1, 2012), available at http://www.cdfa.ca.gov/egov/Press_Releases/Press _Release.asp?PRnum=12-035.

107. Farm Subsidy Payments by Program, ENVTL. WORKING GRP., http://farm. ewg.org/regiondetail.php?fips $=00000 \&$ summlevel $=2 \&$ statename $=$ theUnitedStates $\quad$ last visited Feb. 17, 2013).

108. See, e.g., Eubanks II, supra note 1, at 298; Melissa D. Mortazavi, Are Food Subsidies Making Our Kids Fat? Tensions Between the Healthy Hunger-Free Kids Act and the Farm Bill, 68 WASH. \& LEE L. REV. 1699, 1729 (2011); Wallinga, supra note 29, at 408.

109. Hamilton, supra note 105 , at 549. 
size emerging farmers. ${ }^{110}$ Crop insurance programs that protect farmers from financial ruin when their crop is lost generally do not exist for farms that grow fruits and vegetables or that combine produce and livestock production. ${ }^{111}$ This makes little sense, as these types of systems are generally at a lower risk of costly crop failure or losses since they produce a more diverse range of products. ${ }^{112}$ Similarly, organic food products, which are mostly specialty crops, require a 5 percent premium on crop insurance expenses, but losses are only paid out at conventional crop prices, despite the fact that organic crops sell for higher prices. ${ }^{113}$ In a vicious cycle, the lack of access to comprehensive crop insurance can also reduce access to credit for farmers, because lenders have less reassurance of being paid back on loans. ${ }^{114}$

Small and mid-scale farms and specialty crop producers can also be left out of many price support and incentive programs explicitly as a result of their size. For example, both North Dakota and Pennsylvania provide property tax exemptions or tax reductions for farm property and farmsteads; however, they apply only to farms that are 10 acres or larger. ${ }^{115}$ Similarly, the Model Right to Farm Ordinance used by the state of New Jersey defines a "commercial farm" for purposes of right to farm protections as a farm that is larger than 5 acres, or one that produces agricultural products worth $\$ 50,000$ or more annually. ${ }^{116}$ Only farms meeting these criteria are protected against nuisance litigation from surrounding residents. ${ }^{117}$ These definitions exclude urban farms and small

110. Hamilton, supra note 78, at 129.

111. Susan Prolman, Federal Food and Agriculture Policy, TEDxHarvardLaw Conference (Oct. 21, 2011), http://www.youtube.com/watch?v=W4u-qsXpkZ8; O'Hara, supra note 40, at 3-12, 19.

112. See Joy Harwood et al., Managing Risk in Farming: Concepts, Research, and Analysis, U.S. DEP'T OF AGRIC., ECON. RESEARCH SERV., MARKET AND TRADE ECON. DIV. AND RES. ECON. DIV., AER 774, 14-17 (March 1999), available at https://www.agriskmanagementforum.org/sites/agriskmanagementforum.org/files/Docu ments/Managing\%20Risk\%20in\%20Farming.pdf; O'Hara, supra note 40, at vi, 3-4 (defining risks as including low prices, supply shocks due to damage from weather, disease, or pests, and other declines in profitability).

113. Prolman, supra note 111; O'Hara, supra note 40, at 9-11.

114. O'Hara, supra note 40, at 12.

115. N.D. CENT. CodE ANN. § 57-02-08 (15)(b) (West 2011) (““Farm' means a single tract or contiguous tracts of agricultural land containing a minimum of ten acres ...."); 53 Pa. Cons. Stat. ANN. $§ 8582$ (West 2012) (“"Farmstead.' All buildings and structures on a farm not less than ten contiguous acres in area").

116. State Agriculture Development Committee Model Right to Farm Ordinance, N.J. DEP'T OF AGRIC., available at http://www.nj.gov/agriculture/sadc/rtfprogram/resources /modelrtfordinance.pdf (last visited March 14, 2013).

117. Id. 
agricultural operations. While these limitations only impact a tiny group of very small farms, these explicit biases against small farms should be systematically identified and removed in order to eliminate the barriers to alternative food producers. Small farmers should be afforded the same benefits as large farmers with respect to farm protections, tax incentives, and other agricultural policies.

In addition to the lack of support described above, the industrial food system also has the advantage of an established infrastructure for storage, processing, and distribution that supports large-scale production of commodity crops. This system, based around "oligopolistic supply chains" and "superstore-based retail interfaces"118 is not well-suited to small and mid-size producers. In many cases, there are no longer storage, processing, and distribution networks well-suited to the needs of the alternative food system. In the words of Michael Pollan, noted food journalist and author, "the government could help seed a thousand new polyculture farmers in every county in Iowa, but they would promptly fail if the grain elevator remained the only buyer in town and corn and beans were the only crops it would take." $" 119$

Even the USDA has acknowledged that small and mid-scale food producers are "challenged by the lack of distribution and processing infrastructure of appropriate scale that would give them wider access to retail, institutional, and commercial foodservice markets." ${ }^{\prime 20}$ The federal government, as well as state and local governments, have begun to take interest in this issue by finding ways to support the creation of local or regional "food hubs" that "offer a combination of production, distribution, and marketing services" to these producers, allowing them to access new and larger markets. ${ }^{121}$ But logistical challenges still plague these farmers. For example, most institutional purchasers and large-scale food distributors are now accustomed to purchasing through an efficient and effective industrial system in which massive distributors provide a diverse array of products with ease. ${ }^{122}$ These purchasers often do not want to work with small or mid-size farmers, which would require them to manage various

118. Johnson \& Endres, supra note 74, at 59-60.

119. Michael Pollan, Farmer in Chief, N.Y. TIMES MAG. (Oct. 9, 2008), available at http://www.nytimes.com/2008/10/12/magazine/12policy-t.html?_r=1\&pagewanted=all.

120. James Barham et al., Regional Food Hub Resource Guide, U.S. DEPT. OF AgriC., AgriC. MKTG. Serv., 5 (April 2012), available at http://dx.doi.org/ 10.9752/MS046.04-2012.

121. Id. at 1 .

122. Kelli Sanger and Leslie Zenz, Farm-to-Cafeteria Connections: Marketing Opportunities for Small Farms in Washington State, WASH. DEP'T OF AGRIC., 19 (Jan. 2004), available at http://agr.wa.gov/Marketing/SmallFarm/docs/102-FarmToCafeteria Connections-Web.pdf. 
small deliveries, coordinate with multiple parties, and conduct more preparation on site because small and mid-size producers are more likely to offer raw, unprocessed foods. ${ }^{123}$ The lack of infrastructure for aggregating and delivering the products from these alternative food producers is a key reason for the lack of interest among institutional purchasers in buying from this cohort of producers. ${ }^{124}$

This is not to say that there is no support for small or mid-scale alternative food producers. Over the past four years, the USDA has launched the "Know Your Farmer, Know Your Food" initiative as an umbrella for new programs that encourage small and mid-size producers by supporting direct marketing and regional food systems. ${ }^{125}$ The 2008 Farm Bill also included new supports for alternative food producers, such as creating a Horticulture and Organic Agriculture title for the first time, dramatically increasing the funding for the Specialty Crop Block Grant Program, augmenting funding for the Farmers Market Promotion Program, establishing a new Office of Small Farms and Beginning Farmers and Ranchers, and launching various grant and loan programs to support beginning farmers and ranchers and small and disadvantaged farmers. ${ }^{126}$ The Farm Service Agency's Microloan Program, launched in early 2013, will provide micro-loans under $\$ 35,000$ to small, beginning, and sociallydisadvantaged farmers in order to help them get started and then hopefully "graduate" to other commercial credit opportunities. ${ }^{127}$ Yet this support still pales in comparison to the $\$ 4.9$ billion subsidies provided to

123. Emily Broad Leib et al., Increasing Local Food Procurement by Massachusetts State Colleges \& Universities, HARV. FOOD L. \& POL'Y ClINIC, 28 (Oct. 2012), available at http://blogs.law.harvard.edu/foodpolicyinitiative/files/2011/09/IncreasingLocal-Food-Procurement-by-Mass-State-CollegesFINAL2.pdf; Sanger \& Zenz, supra note 121 , at 21 .

124. Gail Feenstra et al., Using a supply chain analysis to assess the sustainability of farm-to-institution programs, 1(4) J. OF AGRIC., FOOD SYSTEMS, AND COMM. DEV.69, 75 (2011) (finding that institutional buyers most frequently considered "reliable delivery, a ready year-round supply, and availability of local produce from their primary vendor" when considering whether to purchase locally grown food).

125. Know Your Farmer, Know Your Food, U.S. DEP'T OF AGRIC., http://www.usda.gov/wps/portal/usda/knowyourfarmer?navid=KNOWYOURFARME R (last visited Feb. 13, 2013).

126. Renée Johnson, The 2008 Farm Bill: Major Provisions and Legislative Action, CONG. RESEARCH SERV., 5-7 (Oct. 3, 2008), http://assets.opencrs.com/ rpts/RL34696_20081003.pdf; see generally 2008 Food, Conservation, and Energy Act, Pub. L. 110-246.

127. Press Release, U.S. Dept of Agric., Farm Service Agency, USDA Finalizes New Microloan Program, (Jan. 15, 2013) http://www.fsa.usda.gov/FSA/newsReleases? area=newsroom \&subject=landing\&topic $=$ ner $\&$ newstype $=$ newsrel $\&$ type $=$ detail $\& i t e m=$ nr_20130115_rel_0010.html. 
commodity crops in $2011 .^{128}$ If the U.S. wants to ensure that fruits, vegetables, and other healthy foods are available and affordable, "policy makers need to offer at least as much research, financial, and other support to domestic farmers of these crops as has been done for commodity crop growers for decades."129 Financial support should also be directed towards incentivizing farmers to move from commodity production to specialty crop or organic crop production. ${ }^{130}$

Some new supports for alternative producers have also emerged at the state and local level. For example, as a method to encourage new farmers, beginning farmers in Nebraska are eligible for: (1) a three-year lease rather than the typical one-year lease; (2) a \$500 tax credit reimbursement for a required financial management course; and (3) a property tax exemption. ${ }^{131}$ In 2012, Minnesota enacted a statute making loans available to new farmers with limited financial means to spend on agricultural land or purposes. ${ }^{132}$ Similarly, Iowa's Beginning Farmer Loan Program assists new farmers in purchasing agricultural land ${ }^{133}$ and authorizes a range of loan supports and financial assistance to beginning farmers. ${ }^{134}$ Despite these small steps in the direction of assisting small producers, new farmers, and specialty crop operations, much more programmatic support is needed in terms of access to capital, insurance protections, and infrastructure investments in order for the alternative food system to be successful.

\section{B. Legal and Regulatory Hurdles}

As the industrial food system has grown, the legal and regulatory regime related to the food system - including rules that cover everything from food safety to zoning to tax policy-has also been shaped by massive farms and agribusinesses. Unfortunately, legal systems focused on regulating national or international markets often fail to take account of the interests and needs of smaller actors. ${ }^{135}$

128. Farm Subsidy Payments by Program, ENVTL. WORKING GRP., http://farm.ewg.org/regiondetail.php?fips $=00000 \&$ summlevel $=2 \&$ statename $=$ theUnited States (last visited Feb. 13, 2013).

129. Wallinga, supra note 29 , at 408 .

130. Id.

131. NEB. REV. STAT. $\$ \S 77-5201$ to 5209 (2012); see also Beginning Farmer Programs - tax credit programs, NEB. DEP'T OF AGRIC., http://www. agr.ne.gov/beg_farmer/taxcpbfr.html (last visited Feb. 26, 2013).

132. MinN. STAT. ANN. § 41B.01-.23 (West 2012).

133. IOWA CODE ANN. § 175.12 (West 2012).

134. Id. at $\$ 175.1-.37$.

135. Johnson \& Endres, supra note 74, at 69. 
Embedded within the legal and regulatory regimes that evolved to support industrial food are significant barriers for small and mid-size food producers. ${ }^{136}$ According to celebrated polyculture ${ }^{137}$ farmer and food movement advocate Joel Salatin, "[e]very time a letter arrives in the mail from a federal or state agriculture department my heart jumps like I just got sent to the principal's office. And it doesn't stop with agriculture bureaucrats. It includes all sorts of government agencies, from zoning, to taxing, to food inspectors." 138 Though our food and agricultural laws are well-suited to governing large enterprises, they fail to achieve a proper balance when it comes to small or mid-size farmers like Salatin, who wish to sell through local or regional supply chains. When these rules are applied to small and mid-size farmers, who cannot afford to meet the regulatory requirements, they are not able to continue their operations or are unable to bear these costs of production and while still selling their products at marketable prices. These rules, written for large-scale businesses, hamper the success of local producers by "forcing them into a paradigm of regulation designed for industrial practices."139

This is particularly so in the realm of food safety regulation. Small or mid-size diversified farms that grow different crops during different growing seasons have to get their crops inspected separately in order to meet quality standards, rather than being able to have one annual inspection like large industrial monoculture farms. ${ }^{140}$ Small or mid-size food processors are generally required to meet the same certified kitchen requirements as large-scale commercial food enterprises-including building three separate sinks, ensuring complete separation of the kitchen from any living or sleeping quarters, and utilizing countertops and utensils made of specific materials and free of any cracks or chips. ${ }^{141}$

One particular area where federal food safety laws prevent the growth of the alternative food system is in the realm of meat slaughter and processing. Like many other areas of food safety, meat slaughter laws

136. Id. at 66 .

137. Polyculture is defined as multiple crops and/or livestock produced on a single farm. O'Hara, supra note 40, at 4.

138. Joel Salatin, Everything I Want to Do Is Illegal, (Chelsea Green Pub Co., 2007).

139. Trexler, supra note 3 , at 339.

140. Good Agricultural Practices and Good Handling Practices Audit Verification Program User's Guide, U.S. DeP'T OF AgrIC., AgrIC. MKTG. SERV., FrUIT AND Vegetable Programs, Fresh Products Branch, 7- 8 (April 2011), available at http://www.ams.usda.gov/AMSv1.0/getfile?dDocName=stelprdc5097151.

141. FDA Food Code 2009, 4-101.11- 4-202.11, 6-202.112, 6-301- 6-306, available at http://www.fda.gov/Food/FoodSafety/RetailFoodProtection/FoodCode/FoodCode 2009/default.htm. 
were created as a means of regulating large operations, whose food products are transported long distances, and who were responsible for massive food-borne illness outbreaks. Small meat slaughterhouses produce products that do not get into the larger food stream and thus are not responsible for large food outbreaks, yet they are penalized by being subject to a set of costly regulations that are impossible for them to afford.

The Federal Meat Inspection Act requires federal inspection of all meat sold in interstate commerce, and federal or equally rigorous state inspection of all meat sold within state borders. ${ }^{142}$ These meat inspection laws include exemptions for individuals who raise and "custom" slaughter their own animals for personal or household use by that individual and any nonpaying guests, but they do not contain any exemptions or modifications for small producers selling to the public. ${ }^{143}$

After a severe E. coli outbreak in ground beef killed four and sickened nearly 600 individuals across several states, ${ }^{144}$ in 1998 the USDA began requiring meat processors to implement Hazard Analysis and Critical Control Point (HACCP) plans. ${ }^{145}$ This requirement was extended to small and very small slaughter and processing plants in $2000 .{ }^{146}$ Since that time,

142. 21 U.S.C.A. $§ \S 601-25$ and 661 (2012). There are certain situations, however, where meat that is processed in a state-inspected facility can be sold interstate; a new voluntary cooperative interstate shipping program allows the sale in interstate commerce of certain meat products from certain small state-inspected establishments. Id. at $\$ 683$; 9 C.F.R. $\S 321.3$ (2012).

143. 21 U.S.C.A. $§ 623(a)$ (2012). Such custom slaughtered meat cannot be sold, must be kept separate from meat processed for sale, and must be clearly labeled "Not for Sale."Id.

144. Dan Flynn, Ten of the Most Meaningful Outbreaks, FoOD SAFETY NEWS (Sept. 14, 2009), http://www.foodsafetynews.com/2009/09/ten-of-the-most-meaningful-foodborne-illness-outbreaks-picked-out-of-so-many/\#.UPxAJ-Q0WSo.

145. David Taylor, Does One Size Fit All?: Small Farms and U.S. Meat Regulations, 116(12) ENVTL HEALTH PERSP. A528, A529 (2008) (noting that HAACP plans require that a processor "identifies the points in its operation at which health risks might occur, then takes steps to monitor and contain those risks"); see Pathogen Reduction; Hazard Analysis and Critical Control Point (HACCP) Systems, 60 Fed. Reg. 6774 (proposed Feb. 3, 1995) (codified at 9 C.F.R. pts. 308, 310, 318, 320, 325, 326, 327 and 381); Pathogen Reduction; Hazard Analysis and Critical Control Point (HACCP) Systems, 61 Fed. Reg. 38,806 (July 25, 1996) (codified at 9 C.F.R. pts. 304, 308, 310, 320, 327, 381, 416 and 417).

146. Small plants with between 10 and 499 employees and very small plants with one to nine employees or annual sales of less than $\$ 2.5$ million were given an additional 30 months and 42 months, respectively, to comply with the HACCP requirements. See Key Facts: Impact of HACCP Rule on Small Business, U.S. DEP'T OF AGRIC., FOOD SAFETY AND INSPECTION SERV. (July 1996), available at http://www.fsis.usda.gov/oa /background/keysmall.htm; HACCP Implementation-Phase III for Very Small Plants, U.S. DEPT OF AGRIC. FOOD SAFETY AND InSPECTION SERV. (July 1999), 
the number of small and very small meat slaughter plants has decreased exponentially. ${ }^{147}$ The cost of compliance with these federal rules - and the equally rigorous state rules in states that have created state regimes-has created such high barriers to entry that many areas lack federal- or stateinspected meat slaughter and processing plants. Instead, meat must be shipped longer distances, and sometimes even across state lines, for slaughter at an inspected facility, adding considerable transportation costs, which result in higher ultimate prices for consumers. ${ }^{148}$ As a result, many farmers hoping to sell locally-raised meat products suffer from a lack of availability of slaughter and processing facilities. ${ }^{149}$

Meat is surely a high risk product, but the risks often increase with the size of the animal production and slaughter operation, and "regional and locally-oriented food supplies, due to their smaller scale, may be better suited to avoid the higher-risks identified in large-batch processing and animal confinement." 150 This is a market which many farmers would like to enter, and in which there is certainly consumer demand for fresh, highquality meat free from antibiotics and preservatives, ${ }^{151}$ but which remains small and beleaguered as a result of federal law. Some states are starting to identify solutions, such as supporting the creation of mobile slaughterhouses, which are considerably less costly to build and can reach farmers in a broader geographic area, thus allowing the operators to recoup their costs more quickly. ${ }^{152}$ But federal laws could also be modified to fit

http://www.fsis.usda.gov/oa/background/phase3.htm. Small plants are defined as having 10 or more but fewer than 500 employees and very small plants are defined as having fewer than 10 employees or less than $\$ 2.5$ million in sales. Id. .

147. Where's the Local Beef?, FOOD AND WATER WATCH, 3 (June 2009), available at http://documents.foodandwaterwatch.org/doc/WheresTheLocalBeef.pdf ("Between 1998 and 2007, the total number of inspected slaughter facilities fell by 20.8 percent. More "other" facilities, defined as state-inspected or custom, were lost -22 percent than federally-inspected plants - 18 percent."); Taylor, supra note 145, at A530 (noting that "the number of slaughter facilities also shrank by about $10 \%$ " in the period from 1981 to 2008).

148. Where's the Local Beef?, supra note 147.

149. Hamilton, supra note 104, at 15.

150. Endres \& Endres, supra note 87, at 437.

151. See Where's the Local Beef?, supra note 147 at 12; Taylor, supra note 145, at A529; Johnson \& Endres, supra note 74, at 69. Small producers are also more likely to raise grass-fed beef, which has been found to be healthier than the grain-fed beef raised in most large-scale animal feeding operations. See Cynthia A Daley et al., A Review of Fatty Acid Profiles and Antioxidant Content in Grass-Fed and Grain-Fed Beef, 9 NUTRITION J. (2010) (finding health benefits present in grass-fed beef that are not present in grain-fed beef).

152. See, e.g., Vermont Leg., Budget Bill, Act 65 of 2007, Sec. 82(a) (2012); About

IGFC, ISLAND GROWN FARMERS COOP., http://www.igfcmeats.com/2.html (last visited 
small-scale operations, or could explicitly provide for grants, loans, and other supports that would allow smaller enterprises to join the market by helping to defray the high start-up costs they face to meet the regulatory burdens. Even though the health and safety risks and environmental costs of large-scale confined animal feeding operations (CAFOs) have been widely acknowledged, ${ }^{153}$ the current legal structures allow little opportunity to start creating alternatives.

While food safety should be a paramount concern for any food system, food safety laws should not preempt participation of small and mid-size producers, whose operations do not approach the level of risk inherent in larger operations. ${ }^{154}$ But because the regulatory burdens on food producers do not increase in proportion to their size, small and midsize producers are relatively disadvantaged in the marketplace. ${ }^{155}$ In some cases, like that of small-scale meat production discussed above, the barriers to entry may be too great for them to participate at all, despite the fact that "small companies generally contribute proportionately less to the problems justifying regulation" in the first place. ${ }^{156}$ Local food produced on a smaller scale can often be safer because it usually undergoes less processing, comes into contact with fewer points of contamination, and is fresher. ${ }^{157}$ Foods produced on a smaller scale are also less likely to lead to

Feb. 17, 2013). Note that the costs of such units can still be quite high, as they must operate under strict food safety rules, complete costly HACCP plans, and operate under continuous inspection.

153. See, e.g., Mary J. Gilchrist et al., The Potential Role of Concentrated Animal Feeding Operations in Infectious Disease Epidemics and Antibiotic Resistance, 115(2) EnVtl. HeAlth Persp. 313-316 (Feb. 2007); Dick Heederik et al., Health Effects of Airborne Exposures from Concentrated Animal Feeding Operations, 115(2) ENVTL. HEALTH PERSP. 298-302 (Feb. 2007); Peter S. Thorne, Environmental Health Impacts of Concentrated Animal Feeding Operations: Anticipating Hazards-Searching for Solutions, 115(2) ENVTL. HeAlTH PERSP. 296-297 (Feb. 2007); Julie Follmer \& Roseann B. Termini, Whatever Happened to Old Mac Donald's Farm Concentrated Animal Feeding Operation, Factory Farming and the Safety of the Nation's Food Supply, 5 J. FoOD L. \& POL'Y 45 (2009).

154. Schneider, supra note 6, at 951 (noting that our food safety system should not "discourage small farming operations and regional food processing centers through regulatory structures that are impossible for smaller operations to meet").

155. James L. Huffman, The Impact of Regulation on Small and Emerging Businesses, 4 J. SMALl \& EMERGING Bus. L. 307, 313 (2000).

156. Id.

157. Trexler, supra note 3, at 338 (citing Neil D. Hamilton, Farmers' Markets: Rules Regulations and Opportunities, NAT'L AGRIC. L. CTR., 2 (2002), available at http://www.nationalaglawcenter.org/assets/articles/Hamilton_farmersmarkets.pdf; see also Laura B. DeLind. \& Philip H. Howard, Safe at any scale? Food scares, food regulation, and scaled alternatives, 25 AGRIC. \& HUMAN VALUES 301 (2008). Note that smaller scale meat production is also much safer for public health if the farm is not 
the types of large, multistate food-borne illness outbreaks we have seen in recent years. ${ }^{158}$ In light of the reduced risks and smaller operating margins of small and mid-size producers, food safety rules should be both risk- and scale-appropriate, and should make it possible for these small and mid-size food producers to succeed. ${ }^{159}$ Reducing these legal barriers will be essential in order for the alternative food system to thrive.

\section{Barriers to Mid-Size Producers and the Agriculture of the Middle}

Many authors have written about the challenges to small producers using direct markets to sell their foods, ${ }^{160}$ or have called for a "small producer exceptionalism," under which regulators would treat small producers differently than industrial food producers. ${ }^{161}$ However, in order to build alternatives that can truly improve the food environment, we must focus not only on small farmers that sell solely or primarily through direct marketing outlets (such as farmers markets, farm stands, and communitysupported agriculture or CSA models), but also on mid-size farmers who "are the ones best positioned to offer a more diverse set of foods, including fruits and vegetables, to a more local market and have the flexibility to increase production to a larger scale." "162

Sometimes referred to as the "agriculture of the middle," these midsize producers make up the "disappearing sector of mid-scale farms/ranches and related agrifood enterprises that are unable to successfully market bulk commodities or sell food directly to consumers." 163 Definitions of "agriculture of the middle" or "mid-size farms" vary, but most scholars agree that the category includes farmers

using antibiotics, not polluting the waterways with antibiotics and waste products, and not exposing workers to sick animals, as are the practices at many industrial livestock operations. See note 153 for examples.

158. Trexler, supra note 3, at 320-21.

"One infected carcass can contaminate eight tons of ground beef, and a single lot of hamburger was once traced back to six different states and 443 individual animals. ... The rise of foodborne illness traced to food products never before considered to present a problem, like fruits and vegetables, relates not only to the factory farm, but also to the system of centralized processing.". Id.

159. Johnson \& Endres, supra note 74, at 114.

160. See, e.g., Braaten \& Coit, supra note 77, at 22-23; Johnson \& Endres, supra note 74, at 87; Where's the Local Beef?, supra note 147; Taylor, supra note 145, at A529.

161. Johnson \& Endres, supra note 74, at 87.

162. Wallinga, supra note 29, at 407 (citing Fred Kirschenmann et al., Why Worry About the Agriculture of the Middle? AGRIC. OF THE MIDDLE (2004), http://www.agofthemiddle.org/papers/whitepaper2.pdf.

163. What's This About, AGRICULTURE OF THE MidDle, http://www.ag ofthemiddle.org/ (last visited Feb. 19, 2013). 
who cultivate between 100-500 acres, ${ }^{164}$ make between $\$ 50,000$ and $\$ 500,000$ in annual sales; ${ }^{165}$ and are generally too large to sell primarily or solely through direct marketing to local consumers, but are too small to compete in the industrial food system. ${ }^{166}$

Unfortunately, the agriculture of the middle is vanishing. ${ }^{167}$ While both very large farms and very small farms have been increasing in numbers, the number of mid-size farms has been steadily declining. ${ }^{168}$ Between 1987 and 1997 there was an "18 percent sales increase in farms that are 1 to 100 acres in size and a 71 percent sales increase in farms that are more than 1000 acres in size," but "farms in the 260 to 500 acre range averaged a 29 percent decrease in sales." "169 Yet these mid-size farms and food producers are needed to develop viable and sustainable alternatives to the industrial food system. ${ }^{170}$

The decline of the agriculture of the middle may be because mid-size farmers face some of the largest barriers to market entry. Increased interest in local foods and direct marketing over the past decade helped lead to the creation of a set of legislative and regulatory exemptions for sales made directly from farmer to consumer, especially for low-risk foods. Various federal and state legislation and regulations now "ease[] these barriers by removing regulatory burdens that resulted in unnecessary time, cost, and procedural hurdles for small food producers."171 For example, federal food labeling rules exempt small-scale producers who sell their products directly to consumers so long as their profits do not exceed $\$ 500,000$ in annual gross sales and the label "bears no nutrition claims or other nutrition

164. Kirschenmann et al., supra note 70.

165. Characterizing Ag of the Middle and Values-Based Food Supply Chains, AGRIC. OF THE MIDDLE (Jan. 2012), http://www.agofthemiddle.org/archives/2012/01/ characterizing.html\#more (defining mid-sized as "too small to be served well by commodity markets and too large to be served well by direct markets" which mainly includes farmers earning $\$ 50,000-\$ 500,000$ in gross sales).

166. G. G.W. Stevenson et al., Midscale food value chains: An introduction, 1(4) J. OF AGRIC., FoOd Systems, AND COMM. DeV., 27, 28 (2011); Kathleen Merrigan, Beyond Farmers Markets: Why Local Food Belongs on Grocery Shelves, THE ATLANTIC (Sept. 6, 2012), http://www.theatlantic.com/national/archive/2012/09/ beyond-farmers-markets-why-local-food-belongs-on-grocery-shelves/262064/ (noting that "there is a segment of farmers and ranchers who are too small to compete on the global market, but large enough that the proceeds from a farm stand or weekly farmers market are not going to cut it," and for whom we must continue to foster the opportunity to access regional markets).

167. What's This About, supra note 163.

168. Stevenson et al., supra note 166 at 28.

169. Kirschenmann et al., supra note 70 , at 4.

170. See id.

171. Johnson \& Endres, supra note 74, at 116. 
information. $" 172$ USDA rules also contain inspection exemptions for direct marketing of both eggs ${ }^{173}$ and poultry, ${ }^{174}$ with certain restrictions. However, both exemptions are generally limited to direct sales, creating barriers to mid-scale producers who are producing healthy alternative foods and wish to sell to a slightly larger market by utilizing intermediaries or selling to larger institutions. Instead, such mid-size producers often must operate in accordance with the costly regulations intended for larger industrial farms and agribusinesses.

One key example of an exemption for small-scale producers that does not extend to mid-size operations occurs at the state level. Balancing food safety concerns with the opportunity to encourage small-scale food producers, more than 40 states have carved out exceptions to food safety laws in order to allow for "cottage food production." 175 These cottage food laws allow for the sale of non-potentially hazardous foods processed in home kitchens - items like baked goods, jams, and jellies - either without the producer needing to obtain a permit or at least without undergoing the traditional, costly permitting requirements. However, most state cottage food rules impose annual sales caps ranging from $\$ 5,000$ to $\$ 35,000$, which precludes mid-size producers, who generally produce enough to support $\$ 50,000$ to $\$ 500,000$ worth of sales. ${ }^{176}$ Further, states generally require cottage foods to be sold only through direct marketing channels, effectively barring mid-scale operations, which produce too much to sell only through direct-to-consumer sales. In addition, many cottage food laws include burdensome regulations that pose barriers to mid-size operations, or to small producers that are aiming to grow to become mid-size operations. Such hurdles include limitations on the venues in which these foods can be

172. 21 C.F.R. $§ 101.9(j)(2012)$.

173. 7 C.F.R. $\$ 57.100(2012)$.

174. 9 C.F.R. $§ 381.10$ (2012).

175. Emily Broad et al., Legislative and Regulatory Recommendations to Allow Home-Processing of Low-Risk Foods in Mississippi, HaRVARD HEALTH LAW \& POLICY ClinIC, 6 (2010), available at http://blogs.law.harvard.edu/foodpolicyinitiative /files/2011/09/In-Home-Food-Safety-FORMATTED.pdf; additional updated research on file with the author.

176. See, e.g., MinN. STAT. ANN. § 28A.15(9)-(10) (2012) (capping annual sales at $\$ 5,000$ ); Mich. COMP. LAWs $\$ 289.4102$ (2012) (capping annual sales at $\$ 20,000$ until Dec. 31, 2017, then raising the cap to $\$ 25,000$ in annual sales); CAL. HEALTH \& SAFETY CODE $\S 113758$ (a) (2012) (allowing for annual increases in the earnings cap, starting with $\$ 35,000$ in 2013, $\$ 45,000$ in 2014, and capping out at $\$ 50,000$ in 2015. See also TENN. COMP. R. \& REGS. 0080-04-11-.03 (2012) (which includes a cap on the number of units of home-processed products that may be sold, rather than an income limit). 
sold $;{ }^{177}$ limitations on the types of food items that can be produced in a home kitchen; ${ }^{178}$ restrictive labeling requirements that may be expensive to implement; ${ }^{179}$ and permitting requirements that are arduous and costly to meet. $^{180}$

Mid-scale producers suffer from being treated like industrial food system operations in other ways as well. As an example, farmers and food producers selling directly to consumers do not need to undergo any food safety or food quality inspections, but mid-size operations aiming to sell via intermediaries like aggregators or distributors, or to institutional purchasers such as K-12 schools, colleges, and state agencies, are often forced to undergo food quality inspections. The most prevalent such inspection program is the Good Agricultural Practices (GAP)/Good Handling Practices (GHP) certification, developed by the USDA. ${ }^{181}$ While GAP and GHP are voluntary and not required by federal or state law, many large purchasers will not accept food from farms that have not been certified. Certification can be an extremely costly process. At baseline, the annual certification audit costs an administrative fee of $\$ 50$, plus $\$ 92 /$ hour, including travel time, for the audit. ${ }^{182}$ In addition, farms often must make significant additional investments, like installing fencing or toilets, in order to meet the audit criteria. ${ }^{183}$ According to one source, total costs can range from $\$ 500$ to $\$ 1,500$ (and up to $\$ 8,500$ in some cases). ${ }^{184}$ Also, if a farmer

177. See, e.g., AlA. AdMIN. CodE r. 420-3-22-.01(4)(a)(11) (2012); IND. CoDE ANN. $\S 16-42-5-29$ (2012); S.D. Codified Laws § 34-18-35 (2012); МicH. CoMP. LAws $\S$ 289.4102 (2012).

178. For example, some states utilize a restrictive list of products allowed to be produced as cottage foods, rather than allowing in-home production of all nonpotentially hazardous foods. See, e.g., OHIO ADMIN. CODE § 901:3-20-04 (2012); TENN. CODE ANN. § 53-8-117 (2012).

179. See, e.g., TENN. COMP. R. \& Regs. 0080-04-11-.07 (2012); MD. HEALth GEN. § 21-330.1(c)(2) (2012).

180. See, e.g., R.I. GEN. LAWS § 21-27-6.1 (2012); TENN. COMP. R. \& REGS. 008004-11-.04 to .06 (2012); WASH. REV. CODE ANN. § 69.22.030 (2012).

181. Fresh Fruit and Vegetable Audit Programs, U.S. DEP'T OF AGRIC., AGRIC. MARKETING SERVICE, http://www.ams.usda.gov/AMSv1.0/ams.fetchTemplateData.do ?template $=$ TemplateN\&page $=$ GAPGHPAuditVerificationProgram\#P25_1498 (last visited Feb. 21, 2013).

182. Good Agricultural Practices (GAP) and Good Handling Practices (GHP) Audit Programs, CONN. DEP'T OF AGRIC., http://www.ct.gov/doag/cwp/view.asp?a=3243 $\& \mathrm{Q}=465924 \& \mathrm{PM}=1$ (last visited Feb. 21, 2013).

183. To see all of the requirements for GAP/GHP certification, visit: Good Agricultural Practices Good Handling Practices Audit Verification Checklist, U.S. DEP'T OF AGRIC., (Jan. 2012), http://www.ams.usda.gov/AMSv1.0/getfile ?dDocName=STELPRDC5091326.

184. Johnson \& Endres, supra note 74, at 85-86. 
grows different crops at various times of year, they must be audited when each of those crops are grown, meaning that they must undergo multiple audits per year, further adding to the cost. ${ }^{185}$ Because small and mid-size specialty crop producers generally produce a more diverse set of products, they are saddled with these additional certifications and must bear higher costs.

Even though GAP and GHP are not mandatory, they are so widely required that they operate as a set of federally-condoned restrictions on small or mid-size diverse, alternative food producers. The federal government supports this certification program in spite of its negative impacts on alternative food producers, yet it provides no reduction in cost or any assistance to small or mid-size farms. Fortunately, some states have implemented programs to decrease the barriers to quality certification. Massachusetts has developed a state auditing program called "Commonwealth Quality" that is less costly and serves as an alternative to the federal program. ${ }^{186}$ Other states have worked to aid their small and mid-size farms by creating cost-share programs in which the state assists in covering a portion of the costs associated with first-time certification. ${ }^{187}$ But despite these efforts, GAP and GHP certification persists as a barrier to small and mid-size specialty crop producers, particularly impacting those small operations that would like to expand and become mid-size operations, because they are the ones most frequently forced to undergo the inspections.

Luckily, some recent laws that exempt smaller-scale producers from costly regulations have included exemptions large enough to benefit midsize operations as well. The federal Food Safety Modernization Act (FSMA $)^{188}$ created small producer exemptions from its requirements, but these exemptions include a sales cap high enough and marketing restrictions lenient enough to also serve the needs of mid-size producers. The FSMA imposes significant new restrictions on large farms and food

185. USDA GAP \& GHP Audit Program Information, Univ. of Vt. Extension 1, http://www.uvm.edu/vtvegandberry/GAPS/Audit\%20Program\%20Information\%20-

\%20VT.pdf (last visited Feb. 21, 2013); Phil Tocco, Are You Ready for a GAP Audit?, Mich. State Univ. EXTEnsion News (May 25, 2011), http://msue.anr.msu.edu /news/are_you_ready_for_a_gap_audit.

186. Commonwealth Quality, MASS. DEP'T OF AGRIC. RES., http://www. mass.gov/agr/cqp/ (last visited Feb. 21, 2013).

187. See, e.g., Good Handling Practices and Good Agricultural Practices (GHP/GAP), ARIZ. DEP'T OF AGRIC., http://www.azda.gov/ACT/ghpgap.htm (last visited Feb. 21, 2013) (reimbursements will cover up to 75 percent of costs associated with one successful GHP/GAP audit, up to a maximum of \$750).

188. Food Safety Modernization Act, Pub. L. No. 111-353, 124 Stat. 3885 (2011), codified at 21 U.S.C. $\$ \S 2201-2252$. 
processors, authorizing the FDA to develop safety standards for the production of fruits and vegetables for the first time and newly requiring food packing and processing facilities to develop HACCP plans. ${ }^{189}$ After a fierce debate on the subject, advocates were successful in winning some exemptions from the produce safety standards mandated for larger operations for agricultural producers whose operations bring in less than $\$ 500,000$ annually and who sell a majority (50 percent or more) of their products directly to consumers, restaurants, or retail stores, either within the state or within 275 miles of the farm. ${ }^{190}$ In addition to this complete exemption for small and mid-size farmers, small and mid-scale packing and processing facilities (those who meet the same criteria in terms of sales) are exempt from the full HACCP requirements laid out in the statute, and instead may utilize modified hazard control plans. ${ }^{191}$ This is a promising development in terms of creating more scale-appropriate regulation for small and mid-size farms, particularly because the $\$ 500,000$ cap and clause requiring 50 percent of sales to be through direct marketing channels open up the opportunity for mid-size operations to sell through intermediaries and into larger regional markets, while still being protected by the exemptions.

Another positive development was included in the 2008 Farm Bill, which created new programs specifically for the benefit of mid-size food operations. One example is a 10 percent set aside for "midtier food chains" in USDA's Value-Added Producer Grant program, ${ }^{192}$ which provides grants to producers to generate processed or "value-added" products. ${ }^{193}$ Recent federal support for food hubs as methods of creating new infrastructure for regional food systems, mentioned briefly above, will also primarily benefit mid-size farms. ${ }^{194}$

Despite these signs of progress, the challenge remains: in order to create alternatives to the current food system we will need to craft regulations and food safety rules that are risk- and scale-appropriate for both small, direct-marketing operations and mid-size, regionally-focused

189. 21 U.S.C.A. $§ \S 223(d)(1), 350$ g, 350h, 3501 (2012); Food Safety Legislation Key

Facts, U.S. FOOD \& DRUG ADMIN., http://www.fda.gov/downloads/ Food/FoodSafety/FSMA/UCM263777.pdf (last updated July 12, 2011).

190. 21 U.S.C.A. $\S \S 350 h(f)(1)$, (4) (2012).

191. Id. at $\S 350 \mathrm{~g}(1)$.

192. 2008 Food, Conservation, and Energy Act, Pub. L. 110-246 § 6202(b)(7)(c)(ii), codified at 7 U.S.C.A. $\$ 1632 \mathrm{a}(\mathrm{b})(7)(\mathrm{C})(2)$.

193. Press Release: Agriculture Deputy Secretary Merrigan Announces Funding To Create Jobs and Strengthen the Economic Foundation of Rural America, U.S. DEP'T OF AGRIC. (Feb. 3, 2012), http://usda.gov/wps/portal/usda/usdahome?contentid= 2012/02/0040.xml\&contentidonly=true.

194. See supra note $120-1211$ and accompanying text. 
enterprises. Unless we remove the barriers standing in the way of alternative producers, healthy foods will remain unavailable and unaffordable, and we will continue to suffer from poor health outcomes. Accordingly, the time and money spent on bolstering the alternative food system should also be viewed as essential investments in improving our nation's public health. Because many of the barriers to the alternative food system are related to legal and policy choices, lawyers in particular can play an essential role in remodeling the system of food and agricultural law and decreasing these barriers. Part IV describes how this can be done.

\section{The Role for Lawyers in Supporting the Alternative Food System}

As we work to support an alternative food system capable of providing the healthy foods that Americans need to consume, actors from many disciplines will be essential. ${ }^{195}$ Scientists, economists, doctors, public health experts, and especially farmers, food producers, and food entrepreneurs and innovators will need to help the food system evolve so that healthy foods will become more available and affordable. Farm mentorship organizations are needed to link young and aging farmers so that beginning farmers can gain the skills needed to produce our nation's food supply. ${ }^{196}$ Educators are needed to provide nutrition education and culturally-relevant cooking and food preparation classes to consumers so that they will choose to purchase healthy foods if they are available and affordable. ${ }^{197}$

Among this array of different actors, lawyers and the legal profession have an essential role to play in supporting the alternative food system and thereby helping to improve the public health of the nation. As described above, small and mid-size producers suffer acutely from a range of programmatic and policy barriers and legal and regulatory hurdles because they generally are not able to afford the legal expertise needed to help them to learn how to structure their businesses or get the proper permits. ${ }^{198}$

195. Wallinga, supra note 29 , at 408.

"A successful redesign of the food environment will likely require a long-term commitment to mutually supportive interventions, at multiple levels (local, state, and federal) from farm to plate, to effect change in food availability, relative prices, and marketing, complemented by nutrition education." Id.

196. Mills-Novoa, supra note 103.

197. Shelia L. Broyles et al., Cultural Adaptation of a Nutrition Education Curriculum for Latino Families to Promote Acceptance, 43 J .NuTR. EDUC. BEHAV. S158-61 (2011) (describing why cultural relevance in nutrition education is important for efficacy).

198. Johnson \& Endres, supra note 73, at 66. See also supra Section III(A) and accompanying text. 
Indeed, they certainly cannot afford to pay for the services of lobbyists who can help them change the laws that are obstacles to their enterprises. Some change is already afoot, as exemplified by the treatment of small and midsize operations in the Food Safety Modernization Act. But more work is needed. Attorneys can play key roles in supporting the alternative food system by providing legal assistance and counsel to small and mid-size food producers and advocating for policy changes that would lessen the barriers to the alternative food system. Despite recent interest in these important issues from law schools ${ }^{199}$ and legal and policy organizations, ${ }^{200}$ there is much more for attorneys to do to support the success of a viable alternative food system.

\section{A. Provide Legal Assistance to Alternative Food System Producers}

The rise of the industrial food system has led to the development of a complex and comprehensive body of law aimed at large-scale producers, discussed in detail above. Legal challenges pose immense barriers to small and mid-size producers, who lack the resources to conduct legal research or retain counsel. ${ }^{201}$ In instances where the laws are unclear, some small and mid-size producers may decide to forego even legal production or sales methods for fear of inadvertently breaking the law. Basic legal assistance can go a long way towards providing these producers with the requisite tools. The types of services needed could include drafting and analyzing contracts and leases, preparing wills and estate planning documents, and helping to create agricultural easements to protect farmland. Some organizations and entities are stepping in to fill this void. For example, Farm Commons, based in Madison, WI, provides legal advice to small farmers to facilitate negotiation of leases, create CSA programs, form

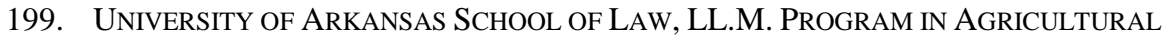
AND FOOD LAW, http://law.uark.edu/academics/llm/ (last visited Feb. 17, 2013); HARVARD LAW SCHOOL, HARVARD FOOD LAW AND POLICY ClINIC, http://blogs.law.harvard.edu/foodpolicyinitiative/ (last visited Feb. 17, 2013); CENTER FOR AGRICULTURE AND FOOD SYSTEMS, VERMONT LAW SCHOOL, http://www.vermontlaw.edu/Academics/Environmental_Law_Center/Institutes_and_In itiatives/Center_for_Agriculture_and_Food_Systems.htm (last visited Feb. 17, 2013); Jay A. Mitchell, Getting into the Field, 7 J. FoOD L. \& POL'Y 69, 73 (2011).

200. See, e.g., NATIONAL Agricultural LAW CENTER, http://www. Nationalaglaw center.org/ (last visited Feb. 17, 2013); NATIONAL SUSTAINABLE AGRICUlTuRE COALITION, http://sustainableagriculture.net/about-us/ (last visited Feb. 17, 2013); THE FOOD TRUST, http://www.thefoodtrust.org/ (last visited Feb. 17, 2013); FARM COMMONS, http://farmcommons.org (last visited Feb. 17, 2013).

201. See, e.g., Johnson \& Endres, supra note 74, at 86. 
business entities, and help plan for farm succession. ${ }^{202}$ Law for Food helps farmers and food producers in New England with a range of legal and business services, including entity formation, estate planning and farm transfer planning, and even trademark and trade secret protection. ${ }^{203}$ Though these organizations can only offer small-scale responses to the legal needs of alternative food producers, both programs are relatively new, and their emergence points to a positive trend towards attorneys forming such entities that can address the needs of the alternative food system.

Attorneys can also help farmers and small food producers think through potential risks inherent in their products and business practices to make sure they are appropriately insured or indemnified. They can assist food producers in understanding the state food processing and cottage food rules, to ensure that these entrepreneurs are able to bring their products to market without incurring unnecessary costs. Lawyers can also play a role in helping food producers navigate the tax policies that apply to farms, ranging from sales tax to estate tax, ensuring that small farmers realize the tax benefits and incentives for which they are eligible. To this end, North Carolina State University Cooperative Extension regularly holds workshops regarding several different tax issues for farmers. ${ }^{204}$

Another key way in which the legal profession can support the alternative food system is by preparing and hosting trainings on some of the above-mentioned legal issues. According to one study, "too many small producers do not know enough about the rules surrounding their small farm businesses," 205 which affords great opportunity for attorneys to assist in training farmers and food entrepreneurs about the legal regime. One group working to meet this need is the Farmers' Legal Action Group (FLAG), established in 1986, which has provided a range of support and advocacy assistance to family farmers for over two decades, including providing over 600 legal trainings and publishing books and manuals on a range of topics. ${ }^{206}$ An attorney can use the experience of helping a farmers market to incorporate as a 501(c)(3) or meet state food safety rules to develop trainings and conduct outreach to assist other farmers markets with

202. What Does Farm Commons Do, FARM COMMONS, http://farmcommons.org/ what-does-farm-commons-do/ (last visited Feb. 17, 2013).

203. Legal \& Business Counsel, LAW FOR FOOD, http://www.lawforfood.com/ Law_for_Food/Services.html (last visited Feb. 17, 2013).

204. Enhancing Sustainability Workshops, CHATHAM CTY. CENTER OF N.C. CoOP. EXTENSION, http://chatham.ces.ncsu.edu/growingsmallfarms/workshops.html (last visited Feb. 17, 2013).

205. Johnson \& Endres, supra note 74, at 106.

206. About FLAG, FARMERS' LEGAL ACTION GRP., http://www.flaginc. org/topics/about/index.php (last visited Feb. 18, 2013). 
these issues. This type of assistance will help new specialty crop producers enter the field and will contribute to the success of the alternative food system and the increased availability of fresh, healthy foods.

\section{B. Advocate for Policy Change to Reduce Barriers to Small Food Producers}

In addition to serving as legal counsel or providing legal trainings, attorneys can identify and support policy changes to remove the barriers to small and mid-size food producers described herein, thus improving the legal and regulatory climate for the alternative food system. Attorneys can help to support the creation of a "new agricultural law," which would include "laws and policies that promote an agricultural sector that produces healthy food in a sustainable manner." 207 Laws at the federal, state, and local level all play a role in creating barriers to alternative food production, so laws at each level require reforms to create a legal and policy setting that can increase the supply of healthy foods. Attorneys can help push for increased access to capital, land, insurance protection, and other types of support for specialty crop production at the federal and state level. They can champion modifications to the rules for small-scale meat slaughter and processing, or fight for financial assistance for small slaughterhouses.

Once legislation is passed, attorneys can assist with proper implementation of the reforms. They can educate farmers and food producers about new laws, ensuring that these new laws are effectively implemented on the ground. Lawyers can help farmers and food entrepreneurs identify new opportunities for innovation available in a new legal landscape. When zoning codes are amended to allow more types of urban agriculture, attorneys can educate potential urban farmers about the avenues for expansion. After states create cottage food exemptions, lawyers should alert communities that cottage food entrepreneurs no longer need to go through an onerous permitting process. The legal profession also has a role to play in ensuring that legislation is effectively implemented through the supporting regulations and enforcement. For example, as the Food Safety Modernization Act is implemented, lawyers should work to protect the hard-won exemptions for small and mid-size farmers and food facilities, vigilantly monitoring implementation of the law in order to retain these protections for the alternative food system. These tasks and many more are crucial to the success of the alternative food system and thus to increasing the availability of healthy, fresh foods.

207. Schneider, supra note 6, at 947 . 


\section{Conclusion}

The unhealthy industrial food system is at the root of today's epidemics of obesity and diet-related disease. A variety of methods have been suggested to help improve the food and agricultural system in order to make healthy foods more available and affordable, and reduce the flood of cheap unhealthy foods. However, until now, not enough energy has been devoted to programs that would support increased production of specialty crops. In particular, since most specialty crop production takes place on small and mid-size farms, resources must be spent paving the way for these alternative food producers to find success. Because so many of the barriers are related to the legal and regulatory regime governing the food system, or are linked with federal, state, and local policies that disadvantage small and mid-size specialty crop producers, the legal profession has a key role to play in helping alternative food producers thrive as well as in advocating for policy changes to improve the climate for their success.

Deployment of financial and legal resources to bolster the alternative food system is essential because investments in the alternative food system are also investments in our nation's public health. As noted by other scholars, investments in the alternative food system can also lead to rewards in other key areas, such as increasing environmental sustainability, improving food safety outcomes, and growing new opportunities for local economic development. ${ }^{208}$ But food system reform is perhaps most urgently needed to compensate for the short-term deficit in the supply of healthy fruits and vegetables required to reverse the course of the obesity epidemic. In order to transform our food system and improve our public health outcomes, we will no doubt need to heed the calls of those who are pushing for reform of some of the worst offenses in the industrial food system so that we can become a healthier society. But in order to provide enough affordable, healthy food to meet the needs of an American public that wants to eat better, we must also lessen the barriers to the alternative food system and make it possible for small and mid-size specialty crop producers to grow America's harvest.

208. See, e.g., Schneider, supra note 6, at 953-54 (noting that "the significant distance between food production and food consumption that marks our current food system contributes to problems for the environment, the loss of nutrients to consumers, and a disconnect between consumers and producers"). 